\title{
INSTANT GLOSS: PROMOTING PAINT IN 1840S PARIS. THE EXAMPLE OF LOUIS VIARD'S CHROMO-DURO-PHANE VARNISH
}

\begin{abstract}
While often operating the margins of propriety, advertisers and marketers are constrained by the social mores of their times. During the early nineteenth century, product promotion opportunities were limited to a mix of newspapers, hoardings and pamphlets. Some enterprising entrepreneurs and innovative individuals pushed the envelope of the acceptable, effectively creating new standards. This paper presents the first case study where the advertising and marketing strategies of a single French entrepreneur are being examined in depth.

To successfully promote his products, the small-scale paint manufacturer Louis Viard employed a range of strategies. These ranged from the true and tried media of newspaper advertisements, product packaging and advertising cards to more innovative modes of promotion, such as mobile advertising on delivery carts as well as flamboyant street processions, to clever and engaging use of billboards and product placement in plays. In addition, he maintained a workforce of loudly attired roaming painters, who combined promotion and marketing at the same time.
\end{abstract}

Keywords: entrepreneurship, marketing, innovation

doi: $10.2478 /$ sho-2021-0004

\section{INTRODUCTION:}

A substantial body of literature has examined the emergent French industrialisation during the early and middle part of the nineteenth century. ${ }^{1}$ David Landes [1949] discussed the role of the French entrepreneur

1 The discussion ranges from general overviews [Caron F. 1995; Heywood C. 1995; Levy-Leboyer M., Bourguignon F. 1990; Smith M.S. 2006] and broad concepts of scale and 
and his influence on French industrial growth during the nineteenth century. ${ }^{2}$ Landes characterised the French entrepreneur as a small businessman acting for himself drawing credit from limited clientele of trusted friends, fundamentally conservative and independent. At the same time, businessmen held an inferior position in French society (as opposed to lawyers, administrators and the military). Businessmen striving to expand their business opportunities could either rely on family connections, reputation and word-of-mouth advertising, or they could engage in promotion to the general public, which, depending on the mode(s) chosen, may have carried the stigma of quackery.

Advertising opportunities during the nineteenth century were a mix of newspapers, hoardings and pamphlets [Feyel G. 2003; Hahn H.H. 2010; Hendon D.W., Muhs W.F. 1985; Mermet E. 1879; Presbrey F. 1929; Sampson H. 1874]. There are a few French texts that summarise the history of advertising in France [Hultquist C.E. 1996; Martin M. 1992, 1994, 2004], some of which focus on the nineteenth century [Martin M. 2004] or were written at that time [Datz P. 1894; Mermet E. 1878, 1879]. By and large these studies comment on the general history of newspaper advertising, or of bill posting on hoardings and walls of buildings. The extant literature on French advertising in newspapers primarily approaches the topic from the angle of the publisher, while the literature on bill posting addresses the nature and artistic merit of bill posters. A small number of studies has compiled and analysed the nature of the actual newspaper advertisements for by small companies and entrepreneurs [Spennemann D.H.R. 2016a, 2016c, 2017a] or for a product offered by various companies [Spennemann D.H.R. 2017b]. These studies, however, are confined to the representation of the advertisements and graphic and textual devices used.

complexity [Doraszelski U. 2004] as well as the role of tariffs and protectionism [Irwin D.A. 1993; Nye J.V. 1991] to wages and their role relating to the industrialisation of urban areas [Cox D., Nye J.V. 1989; Magnac T., Postel-Vinay G. 1997; Sicsic P. 1991, 1992] and the roles played by patents and intellectual property [Machlup F., Penrose E. 1950; Moser P. 2003]. While numerous papers draw on the textile manufacturing and allied industries as examples [Aminzade R. 1984; Lemercier C. 2009] other studies consider 'hard' industries such as iron [Hardach G.H. 1969]. Several papers consider the role of entrepreneurs and individuals [Landes D.S. 1949; Wren D.A. 2001] as opposed to the small scale artisans and manufacturers [Aminzade R. 1984; Lemercier C. 2009; Ratcliffe B.M. 1994] as well as the influences of mechanisation [Edmonson J.M. 1981].

${ }^{2}$ While some of his assertions have come under criticism as being too broad and sweeping, the underlying concepts still apply. 
While some authors, such as Feyel G. [2003] comment on the interplay between advertising in newspapers and on billboards, against the background of governmental oversight, there is no discussion of other advertising media and promotional opportunities such as mobile advertising. ${ }^{3}$ Further, little of the extant research addresses the advertising and promotional practices of medium- and small-scale entrepreneurs. ${ }^{4}$ An exception is a study of the promotion of a cooking appliance by a Parisian entrepreneur [Spennemann D.H.R. 2018] who was more focussed on invention than on commercial success [Spennemann D.H.R. 2017d, 2020, 2021].

While newspaper advertising expanded during the 1820s and 1830s [Feyel G. 2003], space remained at a premium. The French papers of the 1840s and 1850s were usually four-page newssheets, with advertisements printed on page four [Verneuil F. 1838]. The papers allowed for a combination of single and multi-column mainly with text-based display adverts [Feyel G. 2003; Martin M. 2004]. Advertisements by publishing houses promoting their publications led the way, soon followed by varied products. Illustrated advertisements are uncommon, primarily due to the high cost of creating woodcuts as well the costs as advertising space [Spennemann D.H.R. 2017a, 2017b]. Large display advertisements, that had begun to emerge in British newspapers [Lloyd A.J. 2007] were frowned upon by some French publishers, who saw their newspapers primarily as avenues to advance literary content, while other embraced them [Feyel G. 2003]. In this, the developments in France and England has parallels [Lloyd A.J. 2007]. Given the limitations of available column space, numerous publishers preferred to restrict the size of the advertisement which allowed them to offer space to more advertisers - and thus widen the appeal of their paper. Further, like in England at the same time [Lloyd A.J. 2007], some manufacturers and merchants perceived public advertising as unseemly, preferring word-of-mouth and reputation over public announcements. Irrespective of stance, the press of the day exercised much control over the appearance and content of advertisements in their pages, thereby limiting the creativity of the advertisers. Consequently, newspaper adver-

\footnotetext{
${ }^{3}$ For early twentieth century mobile advertising, such as on trams [see: Lefebvre T. 2003].

${ }^{4}$ While some work has been carried out on the marketing and promotional strategies of American entrepreneurs, such as P.T.Barnum [e.g. Cook J. 1999], or of late nineteenth century iconic brands, such as Coca-Cola [Crawford R. et al. 2020; Pendergrast M. 2000] little research has examined the marketing strategies of small-scale French manufacturers.
} 
tisements were, on the whole, far more conservative in their approaches and techniques than posters and handouts [Martin M. 2004].

Bill board advertising, usually with 18 -inch broad sheets, was pioneered by circuses and local music halls in the early 1800s and became common from the 1830s onwards [Hendon D.W., Muhs W.F. 1985]. In France, the Louis Philippe period (July revolution) saw a liberalisation of street advertising, which resulted in the beginning of advertising campaigns [Feyel G. 2003; Martin M. 2004]. The early period of billposting on hoardings ${ }^{5}$ in France, as was also the case in the UK and the U.S.A., was a highly unregulated activity once bill posting per se had been permitted. It appears that any surface was fair game, with or without permission by the property owner, and that roaming bill posters obliterated another bill posters' work within days if not hours [Hendon D.W., Muhs W.F. 1985; Mercier L.-S. 1782: 308; Sampson H. 1874: 26ff]. While early posters were produced by publishing houses advertising large illustrated volumes, and by theatre producers, soon many other merchants saw an opportunity [Feyel G. 2003; Hiatt C. 1896: 11ff; Martin M. 2004; Mermet E. 1879: 109f]. The early posters were text based, often multi coloured, with illustrations limited to woodcuts. The development of chromolithography saw a burgeoning of posters, an appealing, multi-coloured advertising option. Unlike purely text-based posters, the latter were graphically appealing and hence collected. Not surprisingly, then, the majority of specialised research into poster advertising deals with the artistic merits of posters [Hiatt C. 1896; Maindron E. 1896].

The following study will examine the promotional strategies of a single French entrepreneur, Louis Viard, whose promotions employed a broad range of media: newsprint, billboards, flyers, mobile advertising, and performances as well as roving sales people dressed in promotional outfits.

\section{LOUIS JEAN BAPTISTE SERVAIS VIARD (1816-1868)}

While one of Louis Viard's products, the chromo-duro-phane varnish, was a well-recognised product during the late 1840s an early 1850s, Viard himself was not a very prominent businessman. He manufactured paints, in particular a floor varnish, which were in essence ephemeral products; unlike buildings, moveable objects or pieces of art, his paints left little ev-

\footnotetext{
${ }^{5}$ US term: billboards; French term panneau d'affichage.
} 
idence for future historians and heritage researchers to examine. Thus, without much claim to fame, he has so far escaped the attention of historians. ${ }^{6}$ As this paper will show, however, Viard should be recognised as an innovative entrepreneur who in his day pushed the envelope of marketing.

We know comparatively little about the private life of Louis Jean Baptiste Servais Viard. Records show that he was born on 13 September 1816 at La Chapelle-aux-Pots (Oise), as the son of a pottery merchant. ${ }^{7}$ In his late teens he must have moved to Paris, as in 1836 he married Constance Angélique Tencé, the daughter of a Paris paint merchant. ${ }^{8}$ They had at least one daughter (see below). ${ }^{9}$

Viard took over Tencé's paint business in 1837 or 1838, trading as a paint dealer or manufacturer from Tencé's premises at rue Saint Martin $\mathrm{n}^{\mathrm{o}} 54$. For the first few years, Viard seems to have carried on Tencé's business without much innovation and marketing. As far as we can tell, Viard was just one of the many Parisian paint dealers vying for business. ${ }^{10}$

Viard exhibited his 'hydrofuge' paint at the National Industry Exhibition in Paris in 1844 (and again in 1849) and was awarded a Bronze medal. The jury noted that the paint seemed to be successful. ${ }^{11}$ Of course, Viards' water repellent paint could not dry out walls that were affected by

${ }^{6}$ In the absence of personal and company archives, the research presented here draws heavily on a systematic survey of the various nineteenth century French publications, which was enabled by perusal of the Gallica on-line library provided by the Bibliotheque national de France [2015].

${ }^{7}$ Department de l'Oise [2015; 13.09.1814]. For a fully referenced biographical background of Louis Viard see Spennemann D.H.R. [2016b].

${ }^{8}$ Listed as paint merchant in the Paris address books from 1820 to 1840 [see references compiled in Spennemann D.H.R. 2016b]. Tencé's wife also hailed from La Chapelle-auxPots, which suggests prior connections [see Spennemann D.H.R. 2016b].

${ }^{9}$ In addition, there is frequent, albeit erroneous, reference to a son, the communard and anarchist Auguste Vincent Pompée Viard. Research showed, however, that Pompée Viard was the son Louis Viard's first cousin [see Spennemann D.H.R. 2016b].

10 See the various address books for the period.

${ }^{11}$ Listed in exhibition catalogue as 'Viard, Paris, r Saint Martin 54, "couleurs pour préserver les murs de l'humidité" [Anonymous 1844c: 147, n 2882]. Award of bronze medal [Anonymous 1844b: 374, Div. XI §2 no 429; Thénard B. 1844b: 699; 1845: 332]. The cost was deemed low with two coats per metre costing 60 Centimes a meter [Thénard B. 1844b: 699]. Assuming this refers to a running metre of internal walls from floor to ceiling, then we can assume a cost of about 60 Centimes for $2.5 \mathrm{~m}^{2}$. See also glowing commentary by de Saint Aure J. [1844]. 
rising damp. Rather, it seems that the paint acted as a moisture barrier on the inside that ensured that the room, if properly ventilated, stayed dry. ${ }^{12}$

In 1850 he began to expand his business. On 10 January 1850 Viard applied for permission to establish a varnish factory on the outskirts of Paris at Aubervilliers (Seine-Saint-Denis), which was formally granted on 27 November 1851. ${ }^{13}$ In 1851 Viard also moved to new premises at rue Saint Martin $n^{\circ} 128$. Concurrently with the expansion of production, Viard also moved into international markets, for example participating in the 1851 London International exhibition. Viard's Chromo-duro-phane varnish is on record as being exported to Spain in 1853 [Anonymous 1853a] and 1857 [Anonymous 1857]. He also exhibited "[v]arious specimens of colours and varnishes" at the Exhibition of the Industry of All Nations held in New York in 1853 and received an Honourable Mention "for a variety of colours." [Association... 1853: 152; Silliman B. et al. 1853: 12]. This recognition, however, came too late for Viard to use it in advertising as his business failed on 18 August 1853. He had to submit to court-ordered liquidation which seems to have been completed in late 1858 .

After several attempts at sale of the property and the goodwill of the company in 1855 [for details see Spennemann 2016b], Louis Viard's estranged wife, Constance Angelique Tencé acquired the paint factories at rue Saint Martin $\mathrm{n}^{\circ} 124$ once held by her husband. She seems to have carried on the business from late 1856 until about 1864, being in a partnership with her son in-law from August 1858 to late 1861, trading as Viard et Charmy [for details see Spennemann 2016b].

The transition from Louis Viard's bankruptcy to the continued manufacture of paint under his wife's name is too smooth to be coincidental. It can be surmised that Viard and his wife must have had separate commercial entities so that at the time of Viard's bankruptcy, his wife Constance Angelique Tencé may have been a creditor. For the time after the bankruptcy, two interpretations are possible. Either the Viards divorced and Constance Angelique Tencé carried on the business on her own, or Louis Viard remained involved in the business but did not do so in a formal capacity. Louis Viard died in 1868 [Jean de Paris, 1892].

12 If applied to external walls that would have caused the rising damp to emerge at the outside and evaporate there. If applied to two sides of an internal, it would have pushed the rising damp much higher.

13 Préfecture de police [1850]; Republique Francaise [1852]. The water-powered factory ('usine hydraulique') is first mentioned in advertisements of 13 June 1851 [Viard L. 1851a]. The lay-out and physical appearance of this factory is discussed further below. 


\section{CHROMO-DURO-PHANE}

The urbanisation of Paris accelerated after the end of the Napoleonic era, with many rural areas inside the walls of the city being developed as a location of small industry. The centre of Paris saw an increase in the number of multi-storey dwellings with shops on the ground floor and one or more storeys of apartments above, as well as additional multi storey buildings in the internal courtyards. ${ }^{14}$ The walls of the apartments were whitewashed or painted with white lead paint (céruse) ${ }_{1}^{15}$ and later zinc white, while the wooden tile and parquet floors were painted in

"red or yellow colour with a mixture of ochre and linseed oil or Flanders glue; and when this color had dried, to cover it with a wax polish to give it a brilliance, which was maintained by [additional] applications of wax and polishing" [Bouillet M.-N. 1861: 271; for similar comments see Dollingen 1844: 43f].

Viard's varnish had many advantages over the old technique The main selling points for chromo-duro-phane as well as its competitor, 'siccatif brillant' were the fact that the varnish retained its gloss and thus "save[d] the drudgery of scrubbing" to achieve a polished appearance [Bouillet M.-N. 1861: 271]. Moreover, chromo-duro-phane was a varnish

"which dries in two hours, acquires a hardness, a transparency of marble, it gives the tiles or parquet a glow that persists without any kind of rubbing" [de Saint Aure J. 1844].

The lacquering of apartment floors and staircases was an annual event that occurred in mid-summer, when Paris was warm and humid and those, who could afford it, had left on 'les vacances' [Anonymous 1843].

14 See Le cadastre de Paris par îlot, dit atlas Vasserot (1810-1836), Archives numérisées de Paris, Archives de Paris.

${ }^{15}$ Lead poisoning and its effects had been known and reported since the Middle Ages, but effective substitutes for lead based paints, especially white lead (lead carbonate, $\left[\mathrm{PbCO}_{3}\right]_{2} \cdot \mathrm{Pb}[\mathrm{OH}]_{2}$ ) were difficult to find. White lead paint had unsurpassed brightness and also sufficient body to effectively coat surfaces. In the late eighteenth century, de Morveau G. [1783] drew attention to the fact that zinc white was less harmful than white lead paint. There were numerous observations on the harmful effects of red and especially white lead, often called 'painter's colic' throughout the eighteenth century, but public exposure and discussion of the issue did not gain broad-based momentum until the early nineteenth century [e.g. Tanquerel des Planches L.J.C.M. 1839] with the discussion peaking in the early 1850s [Anonymous, 1852, 1853c, 1853b; Bouchut E. 1852; Coulier P.-J. 1852; Sorré 1852; Soudée R. 1852]. 
"While everyone is gone, or about to go, be it abroad, be it to their city, be it to the waters, this is the time to rework the apartments in color" [de Saint Aure J. 1844].

The chromo-duro-phane varnish was essentially a solution of resin wax, alcohol, and turpentine, mixed with a pigment [Chevallier A. 1874: 308f; Girardin J.P.L. 1861: 359; Tripier-Deveaux A.M. 1845: 271f].

Girardin J.P.L. [1861: 359] describes the varnish as a two component paint; whereby component I was comprised of $160 \mathrm{~g}$ lacquer beans and $1 \mathrm{~g}$ yellow wax dissolved in $640 \mathrm{~g}$ of $90^{\circ}$ proof alcohol and strained to remove coarse residue; and component II was comprised of $112 \mathrm{~g}$ yellow pitch, ${ }^{16}$ $112 \mathrm{~g}$ colophane mixed with $144 \mathrm{~g}$ of turpentine. Both components were prepared separately and mixed just before application. The colouring pigments, dry and finely ground, were Prussian red, yellow street ochre, or walnut mixed with umber. ${ }^{17}$

Viard's varnish was not the only one of its kind as at least two other companies advertised similar products with a similar drying time. ${ }^{18}$ Given the competition, the correct branding of Viard's product was of importance. Rather than follow his competitors with descriptive brand names, such as 'siccatif brilliant', 'siccatif luisant', ${ }^{19}$ or even brands based on the manufacturer, such as 'siccatif Moreau', Viard chose a very different route.

As many French commentators later noted, Viard's term ChromoDuro-Phane was a 'burlesque' [Larousse P. 1869: 243] or 'baroque' [Ariel, 1889] word creation intended to sound learned and scientific. It is comprised of three Greek and Latin components, 'chroma' ( $\chi \rho \omega \mu \mathrm{a}$, colour),

16 'Galipot', an impure hardened resin deposits formed on the stem of the maritime pine. The purified version is called purified is called 'yellow pitch,' 'white pitch' or 'Burgundy pitch.'

${ }^{17}$ In 1845 Tripier-Deveaux A.M. [1845: 271f] presents the formula as component I mixed from $5 \mathrm{~kg}$ shellac, $31.25 \mathrm{~g}$ yellow wax and 20 litres of $36^{\circ}$ proof alcohol; and component II comprised of $3.5 \mathrm{~kg}$ yellow pitch, $3.5 \mathrm{~kg}$ colophane mixed with $4.5 \mathrm{~kg}$ of turpentine. Chevallier A. [1874: 308f] mentions a similar component paint, with component I mixed from $480 \mathrm{~g}$ shellac, $3 \mathrm{~g}$ yellow wax and $1920 \mathrm{~g}$ of $36^{\circ}$ proof alcohol; and component II comprised of $336 \mathrm{~g}$ yellow pitch, $336 \mathrm{~g}$ colophane mixed with $432 \mathrm{~g}$ of turpentine.

${ }^{18}$ Monmory et Raphanel. Siccatif Brilliant de Carreaux et Parquets Sans Frottage, advertised to dry in two hours [e.g. Monmory, Raphanel 1842, 1843]. For additional references to advertisements for Siccatif Brilliant see Spennemann D.H.R. [2016a]. See also Monmory's Siccatif Luisant [Monmory 1845].

${ }^{19}$ Siccatif (English: 'siccative') is a drying agent used as a component of paint. 'luisant' is a synonym of 'brilliant'. 
'durus' (hard) and 'phaino' ( $\varphi$ aiv $\omega$, to shine, to glow). ${ }^{20}$ As soon as the term 'Chromo-Duro-Phane' had been coined, it was derided as a melting of "Greek and Latin like shellac with wax... a mangling of entomology" [Guenée A. 1843 [1844]: 371]. Yet soon after its first mention [Viard, 1843a] the term very much entered public consciousness through clever advertising (see below). It was successful enough not only to be included in French dictionaries [e.g. Larousse P. 1869: 243; Migne J.-P. 1857: 540], but also in foreign language dictionaries such as French-Spanish [Dominguez R.J. 1845: 503] and French-German [Sachs K., Villatte C. 1869: 280]. Not surprisingly, Chromo-Duro-Phane was also included in a number of works looking at French word creation [e.g. Darmesteter A. 1877: 244].

\section{PUBLIC RECOGNITION}

Like any entrepreneur at the time, Viard strove for formal public recognition for his products. That could be achieved through participation in the formal exhibitions of the products of French industry, held in Paris every five years; through presentations to the Société d'Encouragement pour l'Industrie Nationale; and through approbation by the relevant professional or scientific bodies.

As one of the commentators of the 1844 Paris exhibition noted, of greater significance than medals won at exhibitions was the formal endorsement by professional bodies. On 7 March 1843 the Chamber of Professional Painters of Paris ${ }^{21}$ recommended Viard's Chromo-duro-phane paint, at the exclusion of other products, as the only suitable floor varnish [see the text on the advertising card Fig. 10]. Given the overall ease of application, and the fact waxing and prolonged polishing was no longer required, it is no surprise that house painters took to chromo-duro-phane as a product. It is to Viard's credit, that his paint was preferred over the rival product 'siccatif brillant.' The economic importance of this endorsement, which was well advertised by Viard [e.g. Viard L. 1845a] and widely reported by sympathetic media outlets [Anonymous 1843, 1844d; Dollingen 1844: 43f], must not be underestimated.

${ }^{20}$ paiv $\omega$ has a range of meanings, from 'to have the appearance of' and 'to bring something to light' to the above used meanings of 'to shine' and 'to glow' [Pape W. 1914: 1250-1].

${ }^{21}$ Chambre des entrepreneurs de peinture de la ville de Paris. 


\section{PROMOTIONAL STRATEGIES}

To successfully market his product, Viard employed a range of strategies, which are discussed below: i) newspaper advertisements; ii) product packaging; iii) advertising cards; iv) mobile advertising; v) roaming painters; vi) billboards; and vii) product placement.

\section{Promotion Strategy I: Newspaper Advertisements and Advertorials}

The most common, and yet most staid form of marketing was to place advertisements in the print media of the day. Heavily text-based advertisements were the initial forms of advertising espoused by Viard in Paris [e.g. Fig. 3; e.g. Viard L. 1843a, 1844a] as well as by stockists in the departments. ${ }^{22}$ These were soon replaced by small two-column display advertisements. ${ }^{23}$ The early version, which featured two small paint pots flanking the title, was very cluttered, trying to cram in far too much detail such as colours and price (Fig. 4). This was soon replaced by a cleaner and leaner layout which carried the product name blocked out in bold letters on a black back ground, with minimal additional text [e.g. Viard L. 1844b]. By 1845 onwards these advertisements not only mention the cost per kg of paint, but also mention that a running metre could be covered at a cost of 75 centimes (Fig. 5) [Viard L. 1845a, 1845e].

All of Viard's newspaper advertisements for Chromo-Duro-Phane fall into the period 1843 to 1845 (Fig. 2), which is, in effect, the first two years after the introduction of the paint. But even then, the documented advertisements were less than ten per year, distributed over a number of newspapers. This clearly suggests that newspapers were not Viard's primary advertising medium.

During the same period Chromo-Duro-Phane was already sold abroad, as we have a single example of advertising reference to sales in Poland [Anonymous 1844a]. ${ }^{24}$ In subsequent years, Chromo-Duro-Phane was oc-

\footnotetext{
22 e.g. advertisement in the Journal de Loiret (Orleans) in June 1843 [Barrault-Martin M. 1843].

${ }^{23}$ For a visual documentation of the advertisements see [Spennemann D.H.R. 2016a, 2017a]. For a discussion of other, contemporary advertisements see [Spennemann D.H.R. 2016c, 2017a, 2017b].

${ }^{24}$ Overall, references to sales in countries other than France are few. While in part this may be an artefact of the (digital) accessibility of foreign language newspapers, it most probably reflects the reality of his reach.
} 
casionally advertised by stockists in various French departments [e.g. Fauvel M. 1851a in Argentan (Orne)].

When Viard went into the business of producing Blanc de Zinc (zinc white) at his Aubervilliers plant in 1851, he engaged in heavy advertising for the new product line (Fig. 2). As before, the advertising period was short-lived, but may have been curtailed by his bankruptcy. In these advertisements he drew on the public recognition of his floor varnish and included, under his address, the tag line "Maison du Chromo-Duro-Phane" [e.g. Viard L. 1851b].

While Mme Viard manufactured paint under her name from 1857 onwards, she does not seem to have advertised. Viard's successors, Viard et Charmy (operated by his wife and son-in-law), continued to manufacture Chromo-Duro-Phane, but with advertisements restricted to 1860 [e.g. Viard et Charmy 1860]. The last marketing reference to Chromo-DuroPhane, now produced by Mme Viard's successor A.Gardin, appeared in 1882 in a Dutch newspaper [Arnold C.H. 1882].

Viard's early advertisements emphasise the fact that the formula for the 'Vernis Anglais' [Viard L. 1843c], ${ }^{25}$ had been developed by "Monsieur Wilson, ex-Professor of Chemistry of the University of Oxford" (Fig. 4). This claim was then also repeated in articles mentioning the paint [e.g Anonymous 1843]. All advertisements with reference to Wilson date to the beginning of production in $1843 .{ }^{26}$

Viard's varnish had to compete with rival products, primarily Monmory and Raphanel's 'siccatif brillant.' Their varnish, which was patented in $1843^{27}$ and had received an honourable mention at the 1844 exhibition, ${ }^{28}$ had a similar drying time and was sold at a similar price as Chromo-DuroPhane [see note 18]. The scientific-sounding branding, and the prominent references to Wilson and the University of Oxford gave Viard's paint formula an aura of a scientific basis with academic excellence. So who was this Professor Wilson? Despite systematic searches, no reference to a professor of chemistry at Oxford with the surname 'Wilson' can be found in

25 Also referred to as 'Composition Anglais' [Anonymous 1847] and 'Mixtion Anglaise' [Barrault-Martin M. 1843]. $1843 c]$.

${ }^{26}$ For adverts mentioning Wilson see [Barrault-Martin M. 1843; Viard L. 1843a, 1843b,

27 Patent for five years granted on 26 October 1843 [Louis Philippe 1844: 307, no 73; Monmory, Raphanel 1849].

28 Thénard B. [1844b: 701-2]. Also exhibited in 1855 [Commission Impériale 1855: 61, no 2543]. 

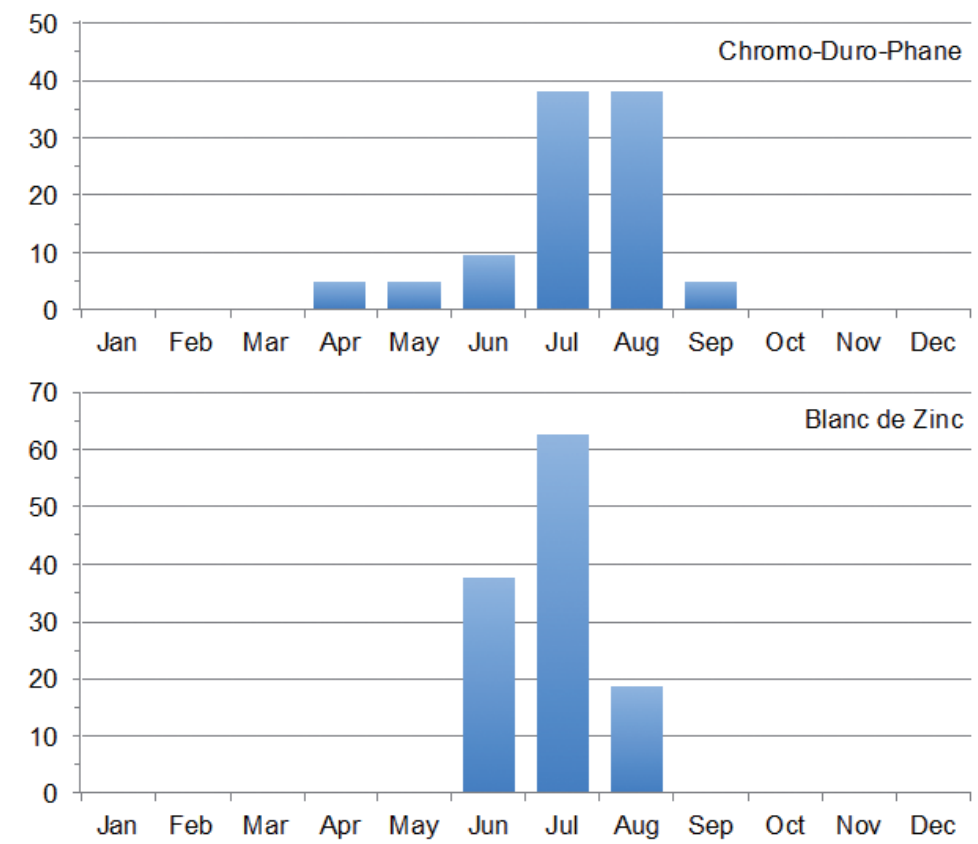

Figure 1. Monthly distribution of Louis Viard's advertisements (in \%) for Chromo-Duro-Phane (1843-1845) floor varnish $(n=21)$ and Blanc de Zinc (1851-1853) wall paint $(n=16)$

Source: Own calculation.

British and British colonial newspapers [Gale 2015; Gale, British Library 2015; National Library of Australia 2016], nor is he mentioned in the archival sources held by the University of Oxford [Millea A. 2016; Williams R.J.P. et al. 2008]. ${ }^{29}$

Given that the main market for Chromo-Duro-Phane was the refurbishment of the Paris apartments in time for the return from the annual holidays, it is hardly surprising that the prime period for advertising was during the summer. Thus the advertisements primarily occurred between April and September, with a pronounced peak during the period of July and August (Fig. 1). The marketing of blanc de zinc, primarily a wall paint

${ }^{29}$ A George Wilson wrote a textbook on chemistry, which dates to the late seventeenth century, with the last edition published in 1736 [Wilson 1699, 1709, 1736]. While the text may have been known to chemists of the day, it is unlikely that the average, well-educated French citizen would have heard of him. 


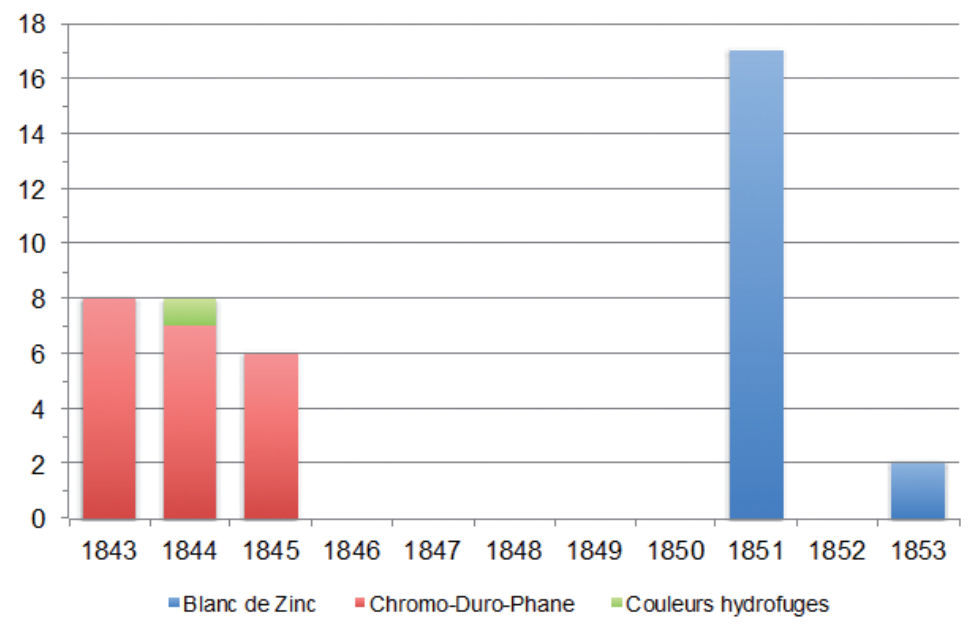

Figure 2. Frequency of Louis Viard's advertisements for his paints 1843-1853.

Source: Own calculation

\section{CIROMRO-BURO-PEANTE.}

La propreté des carrèux et parquets des appartemens, qui est un point essentiel dans lès ńombreux détails de l'économie dornestique, ne s'obtient que difficilement et al prix d'embarras et de sacrifices considérables. Indêpendamment des frais de mise en couleur'et 'd'encauslique, qui ne se-renouvellent que trop sonvent, les maîtresses de maisol: ont à subir les exigences d'un frotteur, dont l'inexactitude et l'incurie sont presque lonjours poirr elles un sujet de tribulation. L'heureuse découverte de M. Wilson, ex-professeur de chímie à l'Université d'oxford, qui vient d'ètre livrée au public sous le nom de Chromo-duro-phañe, est appelée à mettre fin à ces embarras et à ces difficultés.

Dẻpoôt général, chez M. Viard, md de couleurs, tue Saint-Martin, 54.

Figure 3. Early advertisement for Viard's Chromo-Duro-Phane in La Presse in May 1843

Source: Viard L. [1843a].

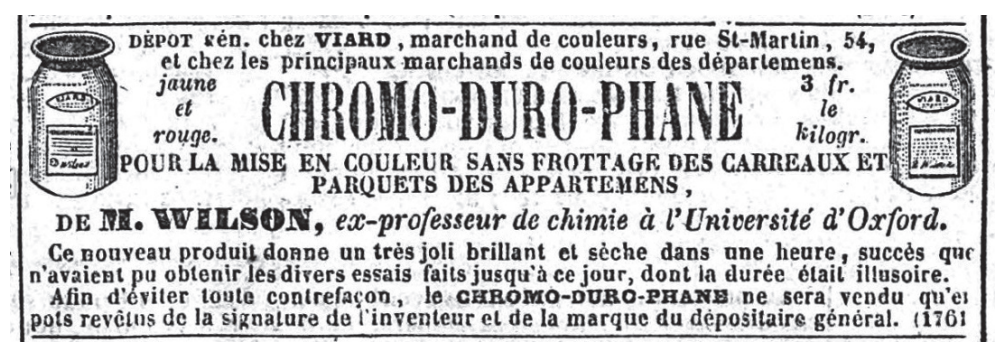

Figure 4. Advertisement for Viard's Chromo-Duro-Phane in the Journal des débats politiques et littéraires in April 1843

Source: Viard L. [1843c]. 


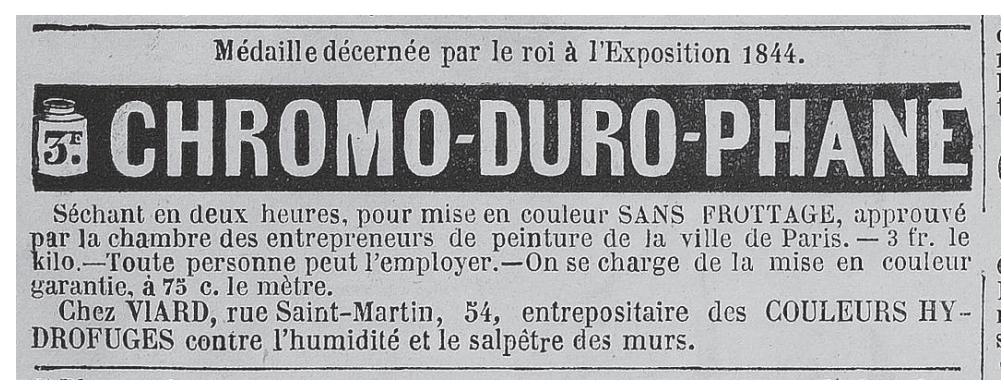

Figure 5. Advertisement for Viard's Chromo-Duro-Phane in Le Charivari of August 1845

Source: Shown is the advertisement of 3 August 1845 [Viard L. 1845e]. Same advertisement but different dates during the month of August 1845 [Viard L. 1845d, 1845c, 1845b, 1845f].

for apartments, was focussed on the June to August period, again the time those families who could afford it, went on their vacation (Fig. 1).

The timing of the advertising, to coincide with the holiday periods, suggests that Viard's marketing was targeting the emergent bourgeoisie.

We have in hand a wood cut that shows Viard's factory at Aubervilliers as it appeared in mid 1853. The view shows the factory and the production yard. The factory is located in the back, the product store at the left and an array of small buildings at the right. These have been clearly labelled, such as (from the right) 'scuries' (slag), 'remise' (wagon shed), 'tonellerie' (cooperage), 'materies diverses' (various materials), fabrique d'vernis (varnish factory) and two inscriptions that are illegible in the reproduction in the Journal des Débats. The people depicted in front of these buildings echo to activities that have been named. Two smoke stacks, one of them belching black fumes, suggest production activity. At the left of the yard is the warehouse ('expedition'), in front of which are numerous barrels and boxes (presumably filled with parcels of powdered paint) as well as a scale and a wheelbarrow. In the left background one can see a laden wagon departing the factory yard.

The main building is a two-storey structure with an occupied attic and a large extension to the right. It appears that the entire façade of the extension is covered with louvers for ventilation. The central tower carries the lettering 'Usine Hydraulique Viard Couleurs Vernis'. The clock shows $8 \mathrm{am}$, which, combined with the activity in the yard, is meant to suggest that factory is running well with lots of orders to be filled. In addition to the production activity, the scene also includes other characters, such as 


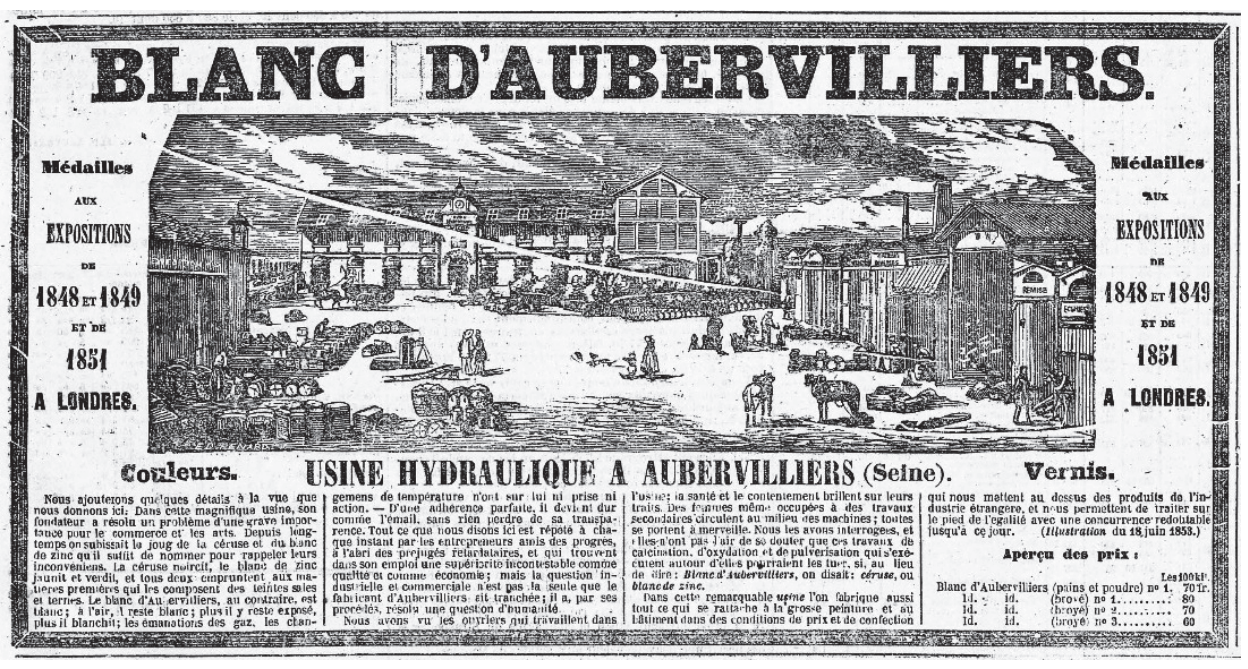

Fig. 6. Advertisement by the Usine Hydraulique à d'Aubervilliers in La Presse Source: Usine Hydraulique à d'Aubervilliers [1853d].

a woman and child who is pointing at the pigeons and chicken in the yard. This inclusion is to create a sense of community and positive working conditions.

The woodcut originally appeared on 18 June 1853 in the weekly magazine l'Illustration, Journal Universel [Usine Hydraulique... 1853b]. ${ }^{30}$ The woodcut was then used by Viard in an advertisement placed on 7 and 12 July 1853 in the daily paper La Presse (Fig. 6), ${ }^{31}$ and again on 20 July 1853, this time in the Journal des débats politiques et littéraires [Usine Hydraulique... 1853c; see also illustration in Spennemann D.H.R. 2016a: p. 17, Fig. 15]. As the column space available for the advertisements in the latter journal was narrower, the woodcut was trimmed at the left margin. ${ }^{32}$

30 The woodcut was created by Eduard Renard (1802-1888), one of the main illustrators working for l'Illustration. Such illustrated magazines can be regarded as an early form of photo journalism [Gervais T. 2005].

31 Usine Hydraulique... [1853a, 1853d]. See also illustration in Spennemann D.H.R. [2016a]. The woodcut as it appeared in La Presse shows a white scar running from the top left through the centre [Spennemann D.H.R. 2016a: 17, Fig. 15]. This is a print flaw in the copy digitised by the Bibliotheque national de France [2015].

32 Both advertisements were four column insertions, but the advertising layout of the Journal des débats was such that placing the same advertisement as in La Presse would have required to purchase a five column advertising space. Hence the wood cut was trimmed to make it fit. The woodcuts in La Presse and Journal des débats politiques et littéraires are compared with the original wood cut as it appeared in l'Illustration. 


\section{Advertorials}

During the early years, Viard marketed his Chromo-duro-phane in a number of newspapers not only by formal advertisements, but also by way of 'advertorials' which were a common ploy in the late 1830s and early 1840s [Feyel G. 2003]. Some were slightly more legitimate, such as overly elaborate comments on his products in the exposition des produits de l'industrie nationale [de Saint Aure J. 1844; Dollingen 1844: 43f], while others were thinly disguised, text-based advertisements masquerading as news copy [Anonymous, 1843, 1844d].

More subtle ways were also used. For example, Frey J. [1844] reviewing a play at the Gymnase, noted:

"During the first intermission, a rain prospectuses of all forms and all colours fell on the fourth loges.

- "I bet," said my cavalier catching the flight a few light shots, "the inventor of the chromo-duro-phane and couleurs hydrofuges does not use these charlatan tricks and uses the honorable means available by advertising in trade and industry.

- You are so convinced of the effectiveness of its products?

- Expecto cude roberto. Excuse me, madam, if I speak Latin, ${ }^{33}$ but ..."

At that moment the curtain lifted on a piece by Paul Duport, La Raison Propose, so boring and so badly played, that I would have preferred to hear, for the hundredth time, the praise of Mr. Viard, of the rue Saint-Martin, the general store of the famous chromo-duro-phane and the no less famous couleurs hydrofuges."

Even though this at first reads like a back-handed compliment ('for the hundredth time') the inclusion of the street address as well the mention that this was 'the general store of the famous chromo-duro-phane and the no less famous couleurs hydrofuges' makes it clear that this was a deliberate mention of his product.

The use of Chromo-duro-phane varnish was not limited to floor coverings. The sculptor Alexandre Joseph Oliva exhibited a plaster model of a bust of Rembrandt in the 1852 salon. The critics mentioned that the bust had been painted with Chromo-Duro-Phane paint and showed a brilliant lustre [Bertall 1852]. ${ }^{34}$ While formally a news item, it still serviced Viard's marketing needs. [for]).

33 'Expecto cude roberto' is not actual Latin with the exception of expecto (= I look

${ }^{34}$ For the bronze version see [Musée d'Orsay 2006]. Wooden statuary, painted with Chromo-Duro-Phane seems to have had the effect of marble [see critique of a Spanish stat- 


\section{Promotion Strategy II: Product Packaging}

The nineteenth century was a period of national and later international exhibitions that showcased the agricultural as well as industrial products of a nation. The Exposition des Produits de l'Industrie Française was held at five-year intervals in Paris. The first truly international exhibition occurred in 1851 in London, followed by the 1853 exhibition in New York [Association... 1853; Silliman B. et al. 1853] and the 1855 international exhibition in Paris..$^{35}$ The award of medals at these exhibitions was, rightfully, regarded as an official stamp of approval and quality. Not surprisingly, successful manufacturers were eager to showcase the fact, both in advertising, as well as on the labels of their products.

Fig. 7 shows a surviving example of a packaging label of Viard's Chromo-Duro-Phane paint, measuring $115 \times 150 \mathrm{~mm} .{ }^{36}$ The red and green coloured label reflects the ornate and cluttered, heavily text-laden lay-out typical of the time. It comprises five zones (Fig. 8). Zone 2 prominently displays the product name in capital letters: 'Chromo-Duro-Phane.' Zone 3 contains explanatory product information in the centre (b), i.e. that the product allows the applications of colour, without rubbing, for stairs, wooden tiles and parquet floors, and that it would dry in two hours. This is flanked at the left (a) by a testimonial asserting that the paint was the only kind accepted by the Chamber of Painters of the City of Paris, and at the right (c) by a statement of provenance (the water-powered factory of paints and varnishes at Aubervilliers).

Zone 4 contains, in fine print, the instructions of application, while zone 5(a) provides the price information (3 Francs per kilogramme), while at the right (5c) we find a comment that all pots of paint would carry Viard's signature as a sign of authenticity to guard against imitation.

ue by Ségoïllot H. 1870: 172]. In addition, the artist Ferdinando Cavalleri is reported to have used the paint in his works [About H. 1855: 60].

35 National French Exhibitions: Exposition des Produits de l'Industrie Française 1823 [Héricart-Ferrand de Thury L.-É.-F. 1824]; 1827 [Héricart-Ferrand de Thury L.-É.-F., Migneron M. 1828]; 1834 [Dupin C. 1836a, 1836b, 1836c]; 1839 [Thénard B. 1839]; 1844 [Thénard B. 1844a, 1844b]; Exposition nationale des produits de l'industrie, agricole et manufacturière Française 1849 [Buffet L. 1850a, 1850b, 1850c]. International Exhibitions: Great Exhibition of the Works of Industry of all Nations, London 1851 [Bowning E.A, 1852a, 1852b, 1852d, 1852c]; Exposition Universelle des produits de l'Agriculture, de l'Industrie et des Beaux-Arts, Paris 1855 [Napoléon P. 1856].

36 The label is in the possession of the author and was acquired in 2016 via an on-line auction house [herve168 2016]. 


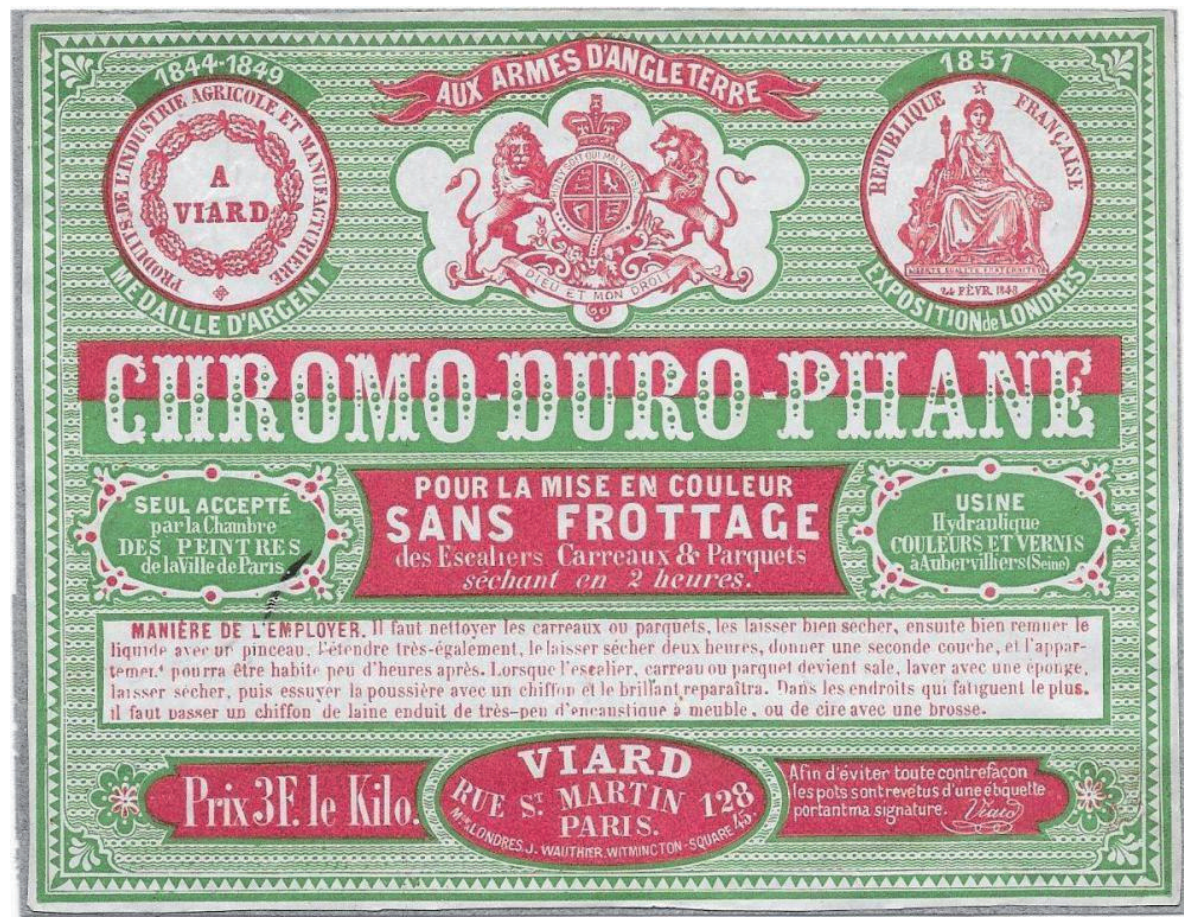

Figure 7. A label for Chromo-Duro-Phane paint manufactured by Viard in Paris (ca. 1851-1853)

Source: Item in the collection of the author. - That label can be dated based on the mention of rue Saint Martin 128, which was the street address from late 1851 onwards (as the terminus post quem), while the mention of the Aubervilliers plant, not used after the 1853 bankruptcy, provides a terminus ante quem.

The centre of zone 5 (b) sets out the address of the manufacturer at rue Saint Martin $\mathrm{n}^{\circ} 128$, with a mention, set in very small print, that that the paint can also be obtained in London from "J.Wauthier, Witmincton Square 45." The latter is a rather curious assertion. In the 1850s, Jules Wauthier, a French barometer maker, lived at Wilmington Square 45, London [Temple P. 2008: 249; see also Goodison N. 1968: 369]. It remains a mystery why a French barometer maker, who did not even advertise his own mechanic objects, ${ }^{37}$ should have been the distributor of Viard's paints in England. Given that paint is such a commonly used item, sold into a market in which Viard had no prior reputation, one would expect

37 Wauthier does not seem to have advertised his services or products in British newspapers [Gale 2015; Gale, British Library 2015]. 


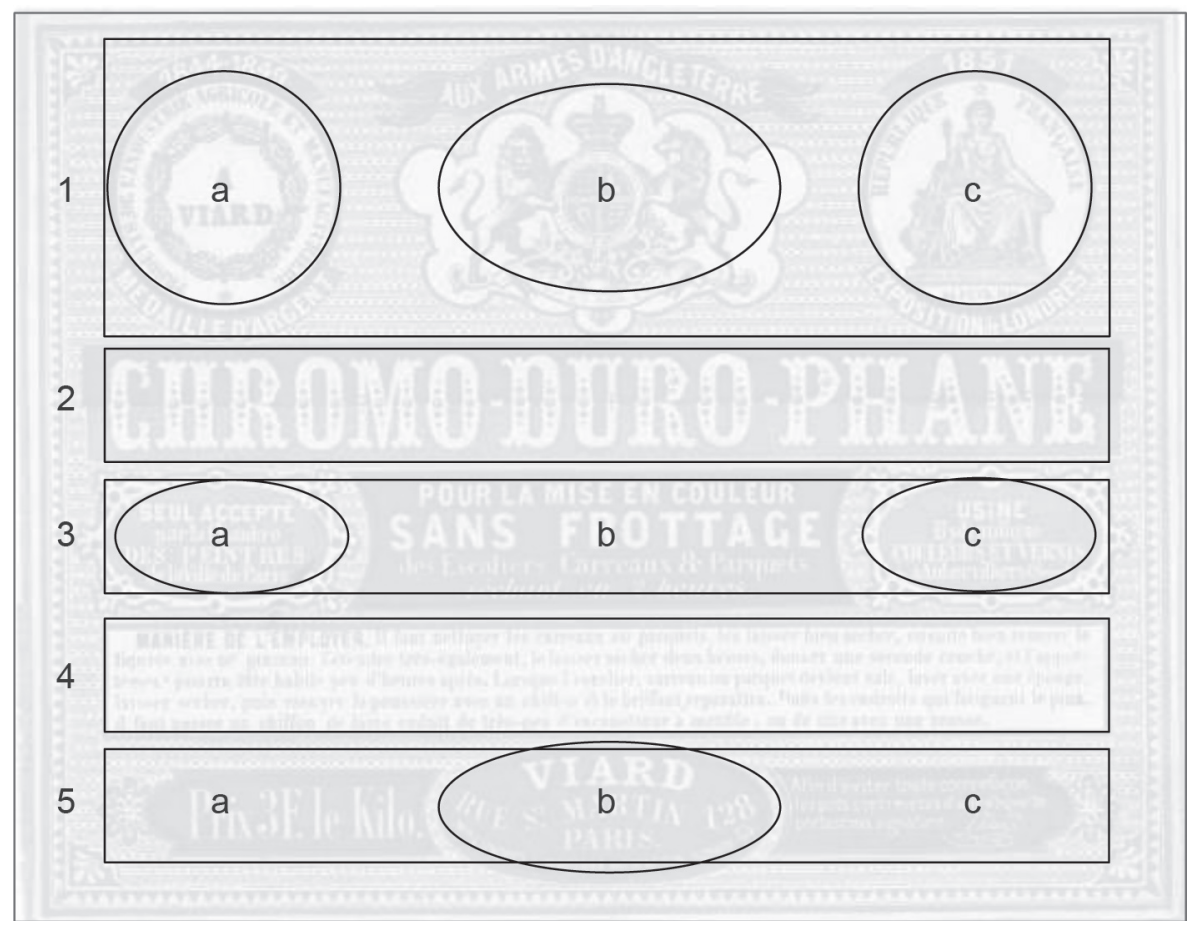

Figure 8. Structure of the label for Chromo-Duro-Phane paint Source: see Fig. 7.

concentrated advertising. Yet there is no reference to Vaird's products to be found in the British newspapers [Gale 2015; Gale, British Library 2015]. The two typographic errors in the word 'Witmincton' suggest that this connection is largely spurious.

The really interesting element of the label is Zone A which crowns the label. If the psychology of people of European descent viewing text, numbers of objects from left to right [Göbel S.M. 2015; Han S., Northoff G. 2008], and also view images in a sweeping, zig-zag fashion from the top left to the bottom right [Chokron S. et al. 2009; Eldesouky D.F.B. 2013] is any guide, then Zone $\mathrm{A}$ is not only the first element viewed, but also be the most portent conveyor of messages.

A cursory view of this zone suggests to a potential purchaser that the product had received two medals and thus was twice endorsed. This impression is reinforced by different texts above and below the medal images. Close inspection, however, reveals that the front and back of the same medal are depicted. The inscription of the left image (a) reads 'Produits de 

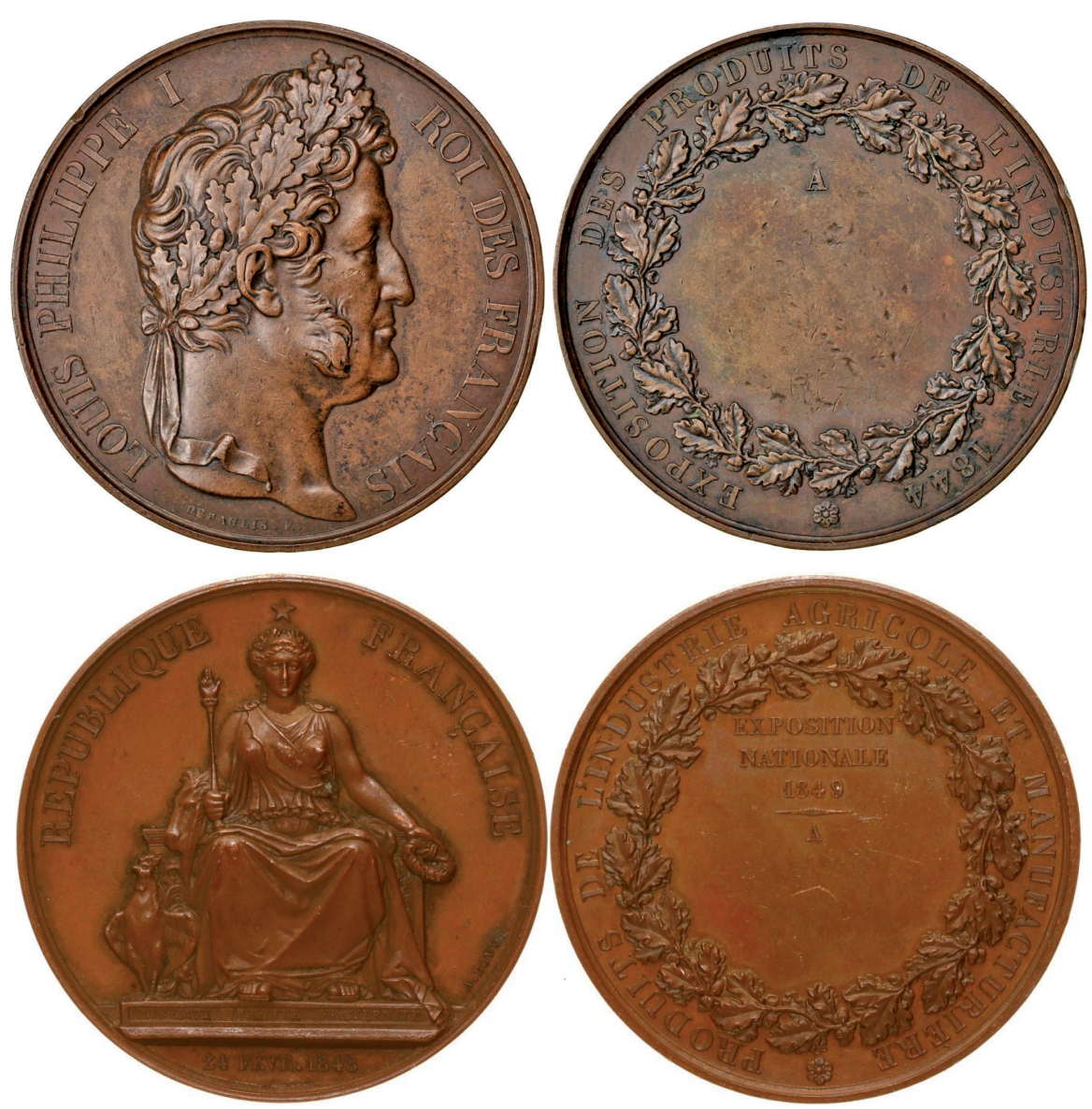

Figure 9. Verso and recto of blanks for bronze medals awarded at the 'exposition nationale des produits de l'industrie, agricole et manufacturière Française.' Top: 1844, bottom 1849.

Source: author's collection..

l'industrie agricole et manufacturiere' with 'A Viard' in the centre. This strongly suggests that this medal was awarded at the 'Exposition nationale des produits de l'industrie, agricole et manufacturière Française' held in Paris in May and June 1849..$^{38}$ The obverse of the medal (shown in section c), which shows an allegorial depiction of France (Fig. 7 bottom) as opposed to the head of Louis Philippe which was shown on the 1844 medal (Fig. 7 top). Further the text above ('1844-1849') and below the med-

38 The title of the previous exhibitions did not specifically mention agriculture or manufactures: 'Exposition des Produits de l'Industrie Française.' 
al image ('Medaille d'Argent') at the left (a) seems to claim that he won a medal at both the 1844 and 1849 exhibitions.

As mentioned, Viard did indeed receive a bronze medal at the national Exposition des Produits de l'Industrie Française in 1844 [Thénard B. 1844b: 699]. When he again exhibited his products at the national exhibition of 1849, the report of the jury mentions his products and makes formal reference to the Bronze medal awarded in 1844 but neither awards him another medal nor an honourable mention [Buffet L. 1850a: 737]. ${ }^{39}$ There is no evidence in the formal jury report that a silver medal was awarded to him at either exhibition. On the other hand, a different, more secondhand, account of honours and medals dispensed at the 1849 exhibition, makes formal a reference ('rappel de médaille') to a silver medal awarded for varnish at the 1844 exhibition [Ministère... 1849: 130]. This appears to be clearly a clerical error, as the 1844 sources unequivocally state that Viard was awarded a bronze medal [Thénard B. 1844b: 699].

Viard seems to have been a master of obfuscation with his marketing strategy always travelling only as close to the truth as absolutely necessary, thereby insinuating 'facts' that set up assumptions in the minds of the readers. This carried through to the listings in the address books. The 1853 address book claims, for example, that Viard had been awarded one bronze and one silver medal at the 1849 exhibition [Henrichs P. 1853: 614]. ${ }^{40}$ His successors, his wife, as well as later Viard et Charmy, were no better; rather, they even inflated Viard's claims. In the 1857 address book, it was not only claimed that Viard had received silver medals for the 1844 and 1849 exhibitions but also asserted that medals had been awarded at the London exhibition (of 1851) and New York exhibition (of 1853) [Firmin-Didot A., Firmin-Didot H. 1857: 539; 1862: 746, col. b; 1864: 761].

${ }^{39}$ Possibly for want of product excellence. This seems to be indicated by the jury comment "Mr. Viard deals almost exclusively in paints against moisture for apartments, and varnish for carriages. The coatings, which leave something to be desired, are however of good quality. The jury recalls the bronze medal obtained in 1844" [Buffet L. 1850b: 737]. The 'rappel de médaille' (recall of a medal) is a proclamation of an award previously granted and that cannot be awarded again [Institut de France 1878: 569]. It is a stretch of imagination to interpret this as a formal second award of a bronze medal.

40 These claims carried through to advertisements placed by other dealers stocking his products. For example, the advertisements the regional paint dealer Fauvel M. [1851b] (at Argentan, Orne) claimed that two medals were won by Viard (1844 and 1849). The placement strongly suggests, without stating so specifically, that the medals had been awarded for the Chromo-Duro-Phane product. 
The latter claim had some substance but substantially stretched the truth (as the award was only an Honourable mention).

The label, as well as the address book entries, make direct reference to the Great Exhibition of 1851 in London, which suggests that Viard had been awarded a medal for his products. Even though France, and in particular Paris was the centre of civilised world as the French perceived it, the importance of international recognition must not be underestimated. This is even more that case if it occurred at the fabled 1851 exhibition in London. A Spanish advertisement of 1856 goes even further and claims that Chromo-duro-phane won a silver medal in London as well as at the Paris exhibition of 1849. The claim of a medal awarded in London was already made in an 1853 advertisement that featured Viard's Aubervilliers factory (Fig. 6), ${ }^{41}$ and is repeated by Mme Viard in her 1857 address book entry [Firmin-Didot A., Firmin-Didot H. 1857: 579]. Close examination showed that Viard indeed exhibited 'samples of colours and varnish' at the Great Exhibition, ${ }^{42}$ which is an achievement in itself, but the official report of the jurors is silent on any award, indicating that the claim on the label, as well as the advertisements, is spurious. ${ }^{43}$

The centre section (b) carried a depiction showing the Royal coat of arms of Great Britain as in use since the reign of Queen Victoria (1837 onwards) replete with the correct mottos and crowned by a banner stating 'aux armes d'Angleterre.' This use normally suggests formal Royal warrant of appointment by the reigning King or Queen of England, in that case Queen Victoria. That claim could not be verified at the time of writing, ${ }^{44}$ but in all probability is spurious.

In summation, for his promotional purposes, Viard seems to have been rather liberal in his use of real and imagined honours and awards. Even though he once faced court for such misrepresentation, it does not seem to have deterred him. 1853c].

41 ‘Médailles aux expositions de 1848 et 1849 et de 1851 a Londres' [Usine Hydraulique...

42 Entry “1521 Viard L. L. 54 Rue St. Martin, Paris. Various samples of colours and varnish" [Yapp G.W., Ellis R. 1851: 248, nº 1521].

${ }^{43}$ Viard Products fell under "Class II, Chemical and Pharmaceutical Processes and Products Generally." The alphabetical listing does not mention Viard [Graham T. 1852: 50].

44 The claim could not be verified at the time of writing as the British Royal Archives at Windsor were undergoing a programme of refurbishment which substantially delayed all responses. 
In 1843 or 1844 M Dulioux, a grocer and self-styled colour merchant and manufacturer at Belleville, claimed to have invented the moisture blocking paint 'vert oxygene hudrofuge,' the rights of which he transferred to Viard in 1844. Viard manufactured and distributed the paint and exhibited it at the 1844 Paris exhibition. It was that paint for which Viard received the bronze medal. Viard used the medal on his billheads, advertising material (Fig. 10) as well at his shop. Dulioux objected, as Viard not only had not been the inventor of the paint, but also used the medal in the advertising of other paints, including chromo-duro-phane (e.g. Fig. 9). Having had to declare bankruptcy in 1846 and in search of funds, Dulioux dragged Viard in front of the commercial tribunal of Paris in October 1847. Dulioux sought a verdict to force Viard to cease and desist using the said medal on stationery, shop signs and advertising, to sever the contract for the manufacture of vert oxygene hudrofuge and to obtain damages. The court ruled in Dulioux's favour but dismissed his request for damages [Anonymous 1847].

It is of interest to note that actual newspaper advertisements of hydrofuge paint were few [e.g. Viard, 1844c]. It appears that the paint was little different from other similar paints on the market and, unlike Chromoduro-phane, not worth specific marketing.

\section{Promotion Strategy III: Advertising Cards}

Pamphlets were a common staple to advertise products from the late seventeenth century onwards [Sampson H. 1874]. The development of lithographic printing in 1796 allowed for the production of graphic images at a reasonable cost. This gave rise to the use of graphics on advertising leaflets and flyers. Most of these, like the product labels discussed above, are ephemera that have rarely survived. We have in hand one such label for Viard's paint products.

The front depicts a street scene, presumably representing Viard's premises at rue Saint Martin 54 (Fig. 10). There appears to be a shop with numerous rows of drawers at the left, while at the right is a drive-way entrance that leads into a large court yard which, presumably, houses the residence as well as the paint and varnish manufacture..$^{45}$ The front façade

${ }^{45}$ We also have in hand a street map and house plan of Paris, dating to 1836 [reproduced in Spennemann D.H.R. 2016b], which shows the property and roughly resembles 


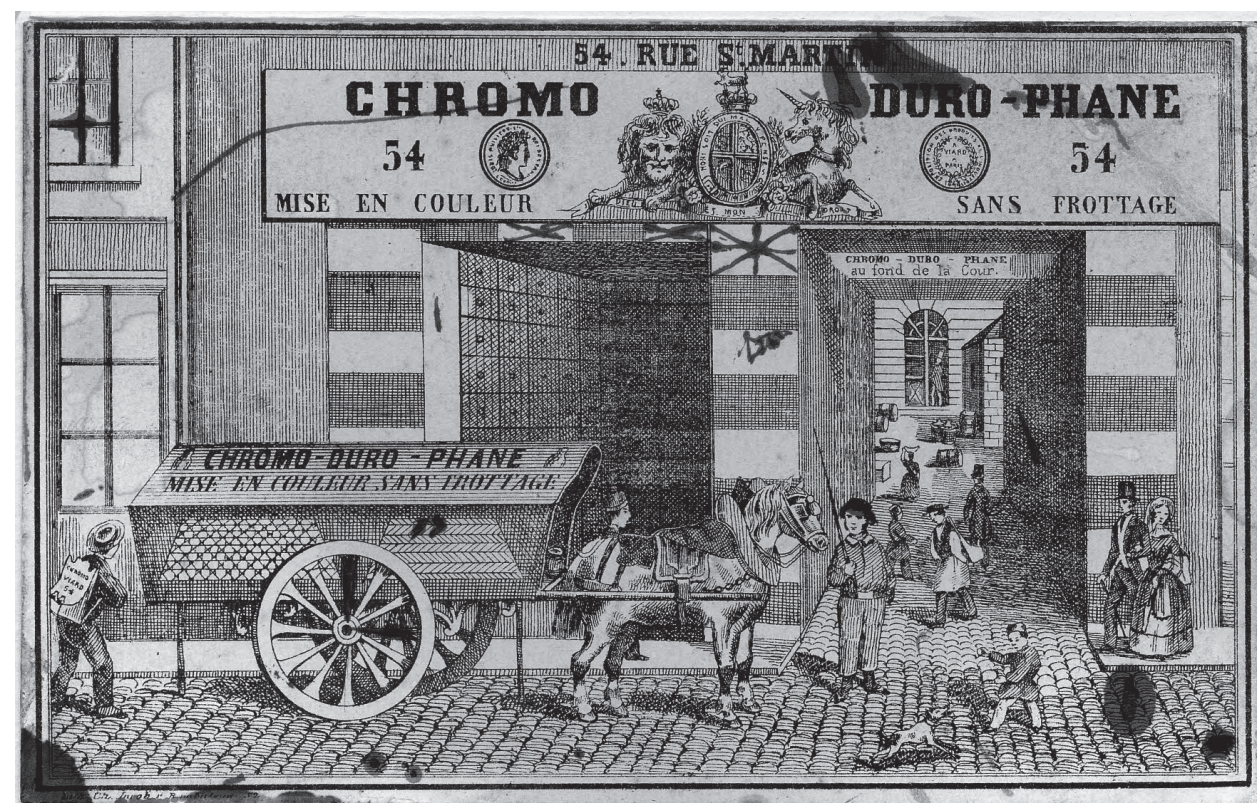

Figure 10. Recto of the trade price list by Viard

Source: Original card is owned by the British Museum, item n ${ }^{\circ}$ Banks, 133.50. (https://www. britishmuseum.org/collection/object/P_Banks-133-50) Reproduction of the image courtesy of the British Museum, London under a CC BY-NC-SA 4.0 license.

of the building shows highly decorated door and window surrounds with alternating light (presumably white) and dark (presumably red) patches of colour. The cobble-stone covered street, as well as the internal court yard, are represented as busy, with a horse-drawn delivery cart with driver, a delivery boy and ancillary people. Among the latter are a boy playing with a dog, as well as a well-dressed couple, suggesting to the viewer that the paint offered was of high quality suitable for the well-to-do bourgeoisie. This is reinforced by a well dressed man walking through the driveway towards the courtyard, and another standing in the dwelling in the rear.

Above the shop and driveway is a large advertising sign with the text CHROMO DURO PHANE mise en couleur sans frottage. Similar to the product label, the centre of the panel is dominated by the British Coat of arms, which is flanked by a graphic representation of the medal awarded

the view from the street as depicted on the advertising card [Le cadastre de Paris...18101836]. 
Figure 11. Verso of the trade price list by Viard

Source: Original owned by the British Museum, item $\mathrm{n}^{\circ}$ Banks, 133.50. (https:// www.britishmuseum.org/collection/ object/P_Banks-133-50). Reproduction of the image courtesy of the British Museum, London under a CC BY-NC-SA 4.0 license.

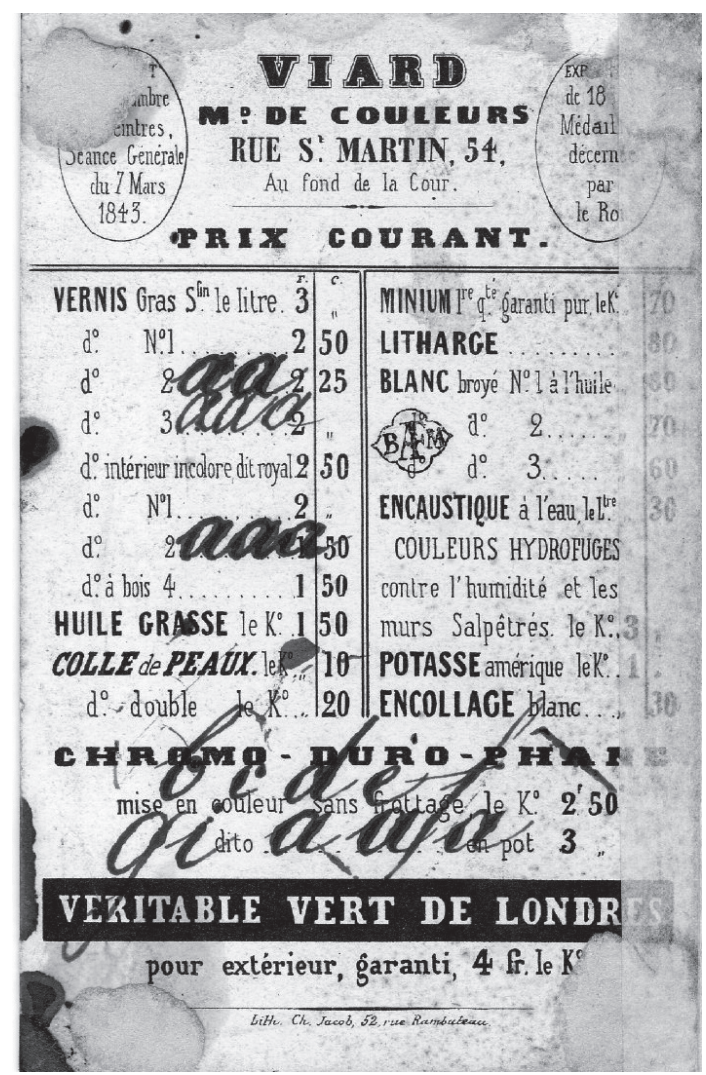

at the Paris exhibition of 1844 . These are in turn flanked, on the outside, by the number 54 . The street address is repeated above the advertising sign.

The verso of the advertising card provides a list of paint products available as well as a list of prices (Fig. 11). It is graphically much less well designed than the front. On the top we have Viard's name and address, flanked by an oval noting that Viard's paint had been selected by the chamber of painters at its general session on 7 March 1843 (left) and that his paint had been awarded a medal by the King on occasion of the 1844 exhibition. The body of the page contains two columns of paints and their prices.

This particular advertising card can be dated to the period between mid-1844 and late $1847 .{ }^{46}$ Such advertising cards were distributed dur-

46 The depiction of the medal awarded at the Exposition des Produits de l'Industrie Française in Paris from May to June 1844 provides a terminus post quem, but likewise a ter- 
ing the intermission of theatre plays. For example, Frey J. [1844] describing a play at the Gymnase, commented that [d]uring the first intermission, a rain of prospectuses of all forms and all colours fell on the fourth loges."

\section{Promotion Strategy IV: Mobile advertising}

In addition to stationary posters on walls and billboards, which will be discussed below, Viard also engaged in mobile advertising, namely on delivery carts as well as by means of street spectacles.

\section{Advertising on Delivery Carts}

The advertising card discussed above shows a two-wheeled horse-drawn cart (Fig. 11). The cover of the cart carries in bold lettering the CHROMODURO-PHANE brand of the paint, with the slogan 'mise en couleur sans frottage' below. There is no reason to assume that this is not a depiction of an actual delivery cart. Closer inspection, shows that the visible side of the cart is covered with samples of floor covering, both wooden tiles (rear) and parquet (front). This is a very clever means of demonstrating to the public the nature and quality of the floor varnish.

Advertising in newspapers and on bill boards provided for product awareness and recognition, which then had to be converted into a purchase. The fast drying lacquer varnish was such a departure from the long established tradition of polished waxed floors, that it invited scepticism. As the Chromo-Duro-Phane varnish was applied to the floors of private residences, Viard had no easy way of demonstrating the quality of the varnish to the general public. While word-of-mouth was certainly an important avenue (as it essentially came with the endorsement of a friend or neighbour), it was too limited in its reach. Mounting samples of treated floor coverings on the sides of the cart(s) made the samples accessible to all people. Significantly, it allowed for a close inspection of the varnish, both through optic and haptic senses, as applied on actual flooring materials.

minus ante quem as Viard had to desist from using the medal in his advertising as per court ruling of November 1847. 


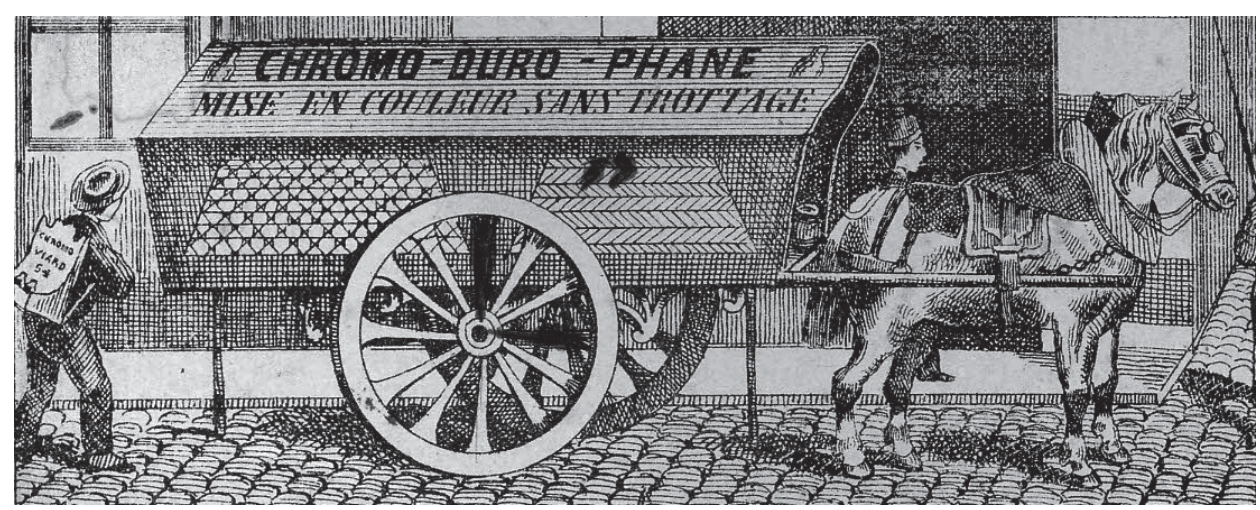

Figure 12. Detail of an advertising card Source: see Fig. 9 for complete card.

Street Spectacles and Processions

Another high-profile component of mobile advertising was the participation in annual carnivals. Traditionally, Shrove Tuesday was celebrated in France with masked balls as well as a street carnival, of which the Promenade du Boeuf Gras, a procession parading the fattest oxen through the streets of Paris, was a major annual event. After several year's absence, the spectacle was revived in 1851 by Lucien Émile Arnault, director of the theatrical circus L'Hippodrome au Pont de l'Alma [Darthenay 1851]. This choreographed parade of the well-decorated oxen was accompanied by an entourage dressed in colourful clothes. The event spurred on several merchants to copy the spectacle and to hold their own parades during MidLent ('Mi-Caréme'). As an anonymous writer noted in Le Ménestrel,

"[t]he Thursday of mid-Lent was more animated than usual. The skinny-fat oxen of the Hippodrome, operated by Mr. Arnaud, have created a vivacity of the Parisian industry for which advertising in major newspapers is no longer enough" [Anonymous, 1851a].

A number of descriptions exist for two processions which were held despite pouring rain, 'competing with each other for pomp and glitter' [Anonymous, 1851b]. One parade was organised by 'la maison de confection du Prophète', a clothing and drapery store ${ }^{47}$ the other by Viard.

47 'La maison de confection du Prophète', fielded the character of the prophet on a chariot accompanied by a retinue dressed in thirteenth century clothes and followed by a chariot with mustard pots of all sizes preceded by a band of pike bearers and followed by 
Viard's procession comprised a chariot carrying a personification of chromo-duro-phane, which was preceded by a music band and surrounded an entourage on foot and on horses, dressed in gilt, velvet and silk costumes. Horsemen carried banners with Viard's address. One of the two processions, presumably Viard's, was accompanied by a 'giant snail containing the Parisian committee of sympathetic snails' [Anonymous 1851a, 1851b; Lalire C. 1851; Martin E. 1851]. ${ }^{48}$

Commerson's magazine Le Tintamarre, which both carried and critiqued advertising, noted that

"[ $\mathrm{t}]$ he industrialism that occurs about everything and about nothing, these days seizes the street, puts a false nose to his chromo-duro-phane, a bump to the overcoats of the Prophet" [Martin E. 1851].

Yet, despite such commentary, the processions were successful and had Paris talking - the very effect the companies had desired. For example, the procession showcasing chromo-duro-phane was reported in many newspapers in Paris [Anonymous 1851a, 1851b; Martin E. 1851] as well as in the departments [Lalire C. 1851]. The publication of course broadened and reinforced the publicity this event had already generated.

\section{Promotion Strategy V: Roaming Painters}

The advertising card discussed above also shows a boy or young man to the left two-wheeled horse-drawn cart (Fig. 11). Carrying on his back a wooden pannier with paint, he is either a roaming painter or, more likely, a delivery boy. ${ }^{49}$ In the depiction, the pannier is inscribed with the text "CHROMO VIARD 54." We can assume that a real life example of such a pannier would have carried the full name and address.

In his series 'Les Petits Industries' in the magazine L'Illustration, journal universel, Paul Flamant pilloried the idiosyncrasies of many small-scale

servants dressed in costumes of the seventeenth or eighteenth century [Anonymous 1851a, 1851b; Lalire C. 1851].

48 The concept of sympathetic snails ('escargots sympathiques') had been advocated by Jules Allix (1818-1897) in 1849. To the amusement of all of Paris, Allix had argued that snails that had mated would stay in constant communication. Thus, if someone in Paris were to touch a snail representing the letter ' $\mathrm{P}$ ', the snail representing the letter ' $\mathrm{P}^{\prime}$ would move, say in Beijing. A flawed experiment conducted in 1850 had convinced Allix that this phantastic idea might work.

${ }^{49}$ A second figure with a pannier on his back, an adult male, can be seen in the archway. 
entrepreneurs in Paris, some of which wore quite elaborate dress to attract the attention of the passers by. In October 1850 he described painters peddling the Chromo-Duro-Phane product on the streets in the following way: ${ }^{50}$

\begin{abstract}
"And here is new industry that was born yesterday; we mean the application of colour without sanding apartments. ${ }^{51}$ The young artist that you see depicted in this engraving [e.g. Fig. 12], who at first looks like both Neapolitan pulcinella, carries on his suit the insignia of his profession. It has a hatstyle shaped as a pot of colour; on his blouse and trousers we see red patches resembling octagonal tiles. The small Parisian property owner needs to put a new varnish on his tiles, which have been scuffed by too much use, and within seconds the man with the tiles and the colour port performs a metamorphosis with his brillant siccatif, ${ }^{52}$ the new preparation does not need, like the old, to be polished for a long time. The siccatif dries by the minute" [Flamant P. 1850].
\end{abstract}

This marketing of course worked on the principle of repeated recognition of a familiar product aided by consistent branding, as all itinerant painters would have been dressed exactly the same colourful way. Further, the tall paint pot-shaped hat, which clearly references the headgear of Napoleonic and post-Napoleonic soldiers [see Elting J.R. 1993], would have stood out among the crowd as would have the colourful dress.

While mobile services such as copper polishers and drink merchants ('marchand de coco') were not uncommon [Flamant P. 1850], they tended to work for themselves. Viard adapted and enlarged the concept. He despatched itinerant painters who acted as a mobile sales outlet for his paints, as a mobile labour force carrying the supplies they needed for a job, and as roaming advertisements. This set up also allowed Viard to induce customers to impulse-buy his product and have it applied without the need to source a painter.

We can assume that much business would have been obtained by word of mouth recommendations of the final product and by the nearinstant gratification of the commissioning homeowner. Thus these roaming painters represented not only a form of mobile advertising but also allowed for experiential marketing. ${ }^{53}$

50 The original text [Flamant P. 1850] was reprinted several times by Texier E.A. [1852: 249f; 1854: 24ff; 1867a: 60f; 1867b: 967].

51 . The French original 'mise en couleur sans frottage des apartments' [de Genouillac, H.G. 1882] references part of the advertising slogan (see Fig. 7).

52 The drying additive to varnish and paint.

53. For another example of experiential marketing, see Stanislas Sorel's marketing of of his cooker [Spennemann D.H.R. 2018]. 


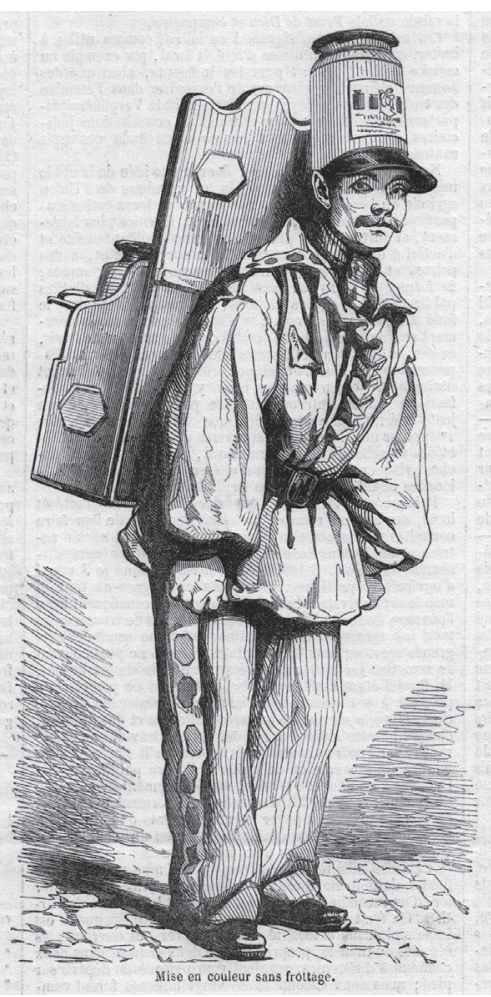

Figure 13. Street seller peddling Viard's Chromoduro-phane floor varnish in 1850

Source: The unsigned illustration, probably by L. Chantal, first appeared in 1850 in L'Illustration, journal universel [Flamant P. 1850], was then reproduced in Texier's book of 1852 [Texier E.A. 1852: 250] and finally reissued in colourised form as image $\mathrm{n}^{\circ} 111$ in the pictorial volume "Costumes de Paris a travers les siecles" [de Genouillac, H.G. 1882]. The colouring of the 1882 reprint is purely speculative. A metric and graphic comparison shows that both the 1852 and the 1882 reprints were printed from the original plates

\section{Promotion Strategy VI: Billboards}

Billboard advertising was common during the early nineteenth century in both France and the United Kingdom. We can safely assume that to further his product recognition, Viard resorted to generic billboard advertising as well. We have this on record for 1845 [Anonymous, 1845] as well as $1851 . .^{54}$

${ }^{54}$ Indeed, Busoni wrote in 1851: "The Parisian vacationer, not knowing how to use his Easter vacation, was advised to resume his walk along the boulevards of Longchamps. On the chaussée, the elegant carriages and fashionable centaurs cross and prance with the cavalcades of industrialism; when the flâneur moves, the advertisement follows him everywhere like a shadow; it walks, it runs on his trail, the banner raised and the ensign deployed, firing its products down the line of the boulevards: dresses, cirases, seltzer, chromo-duro-phane, March beer, lottery tickets and tailor-made clothes. What would Molière have said of this masquerade? ....Moralists still observe with pain that in this industrial display the suspect products are precisely those who walk in great pomp; the public pays generously for the luxury while for the other there is little or no reward" [Busoni P., 1851]. 
The elections for the French Constitutional Assembly on 23 and 24 April 1848 gave Viard an opportunity to engage in a very entertaining way of advertising. Given that these were the first elections since 1792 where the entire (male) population, and not just the tax payers, had a vote, the event generated much interest among the French citizens. In the run up to the elections, candidates would often post a bill on walls with the call ‘CITOYENS NOMMONS' (Citizens Appoint) printed in large bold letters, followed by the names of the candidates [Boucher H. 1908: 99, entry for 14 September 1848]. Very cleverly, Viard played on this when he developed a memorable advertising campaign. As Sarcey F. [1882: 238f] recalled in his 'Le mot et la chose':

"[t]he advertisement is often joking and jovial. It seeks to have fun, because it is for people who like to laugh. Who does not remember the 1848 advertisements ... which occurred during the elections and at the time were successfully causing [much] laughter :

\begin{tabular}{|c|}
\hline CITIZENS, APPOINT \\
the \\
Chromo \\
DURO \\
Phane \\
is sold at..."
\end{tabular}

P. Duverger [1864], discussing the advertising of the times as le humbug d'origine britannique, mentions a very similar multicoloured advertisement ${ }^{55}$ and commented that

"from a distance, the three strange words, written in large capitals, seemed to many the names of citizens aspiring to be part of the national assembly. More than one naive voter, it is said, gave his vote to Chromo Duro Phane" [Duverger P. 1864].

P. Flamant [1850] when discussing the Chromo-Duro-Phane street sellers (see above) also referred to these advertisements.

"This is the colour director of apartments, who, during the 1849 elections, ${ }^{56}$ improvised on the walls of the capital the unexpected nominations of Chromo, Duro, Phane; these

55 Appoint | CHROMO | DURO | PHANE | "the best drying varnish which is to put the apartments in color" [Duverger P. 1864].

56 The first formal elections for the French National Assembly for the Second Republic were held on the $13^{\text {th }}$ and $14^{\text {th }}$ of May 1849. 
were the names the Athenians were to elect as archons? In the Legislative Assembly the names Chromo, Duro, Phane were not known, but they served to publicize and popularize an invention and an industry now travelling under full sail, pushed by the breeze of puff."

Another poster, which in addition made good use of the selective choice of oversized and small print, reputedly ${ }^{57}$ read [Ariel 1889]:

\section{IT IS THE $12^{\mathrm{TH}}$ OF JULY}

we usually choose to put our apartments in color. All

$$
\text { GOOD CITIZENS }
$$

will agree to fix their choice on

CHROMO

DURO

PHANE

No hesitation! No division! No abstention!

Once these advertisements had caused enough of a stir and had most of Paris talking, they were followed by a second round of billboard advertising:

"I remember a poster that was a colossal success in 1848. Parisians of that time saw one day pasted on the walls, a huge sign bearing in large letters the dazzling words:

PEOPLE, DECEPTION!

Naturally, onlookers approached and then read, written below in small letters: 'The real chromo-duro-phane, etc.' That was it. The people had the address of the quack" [Flammèche N. 1873].

Another example, likewise working in reverse to the NOMMONS poster, makes extreme use of the differences in font size and thus required the reader to step up closely to read the advertisement in order to make sense of it [Anonymous 1854]:

57 The date used in the cited example is erroneous, however, as none of the 1848, 1849 and 1852 elects were held in July, nor were any of the subsequent elections (in 1857, 1863, $1871,1877,1881$ and 1885). 


\section{CITIZENS DO NOT FORGET}

when lifting the carpets, the Chromo-Duro-Phane varnish

for the application of colour without rubbing, the only one accepted by the ASSEMBLY

of painting contractors, etc.

While the proliferation of posters on plastered over public buildings and monuments drew criticism [de Rattier P.E. 1857: 42], it does not seem to have adversely affected his business. In fact, Viard's strategy of tonguein-cheek advertising must have been rather innovative ${ }^{58}$ and thus very memorable as it is recalled and recounted in numerous French publications during the remainder of the nineteenth century [e.g. Ariel 1889; Claude A., Labourieu T. 1883: 50f; Duckett W. 1867: 149; Labourieu T. 1853]. ${ }^{59}$

\section{Promotion Strategy VII: Product Placement}

A more subtle way of advertising via product placement in movies is a well known form of semi-subliminal marketing [Newell J. et al. 2006; Segrave K. 2004], but this is hardly a new development. Such product placement already occurred in the Parisian Vaudeville revues of the 1840s and 1850s. If executed subtly and aptly it worked well. If the placement was too obvious, however, it could offend the audience [e.g. Holff C. 1853: 43]. Product placement of Chromo-Duro-Phane is reported, for example, in the play Les Premières Armes de $1852 .{ }^{60}$ In Viard's case, however, product recognition had already been achieved by the various means discussed above, so that the Vaudeville components just added to the concept of repeated recognition of a familiar product. It is important to note, however, that the audience of these Vaudeville shows comprised of elements of the bourgeoisie which, as apartment owners, formed his primary clientele and also of those aspiring to be upwardly mobile and one day join the ranks of the

58 It seems that Viard's strategy was then copied by merchants as well. Duverger P. [1864] makes reference to shoe maker ('The Revolution Marches on!') and a hat maker (I demand 100,000 heads!).

59 The CHROMO | Duro | PHANE advertisement was also referenced when discussing unusual electioneering practices in general [Jean de Paris 1876; Richard J. 1869].

60 The annual revue premiered on 27 December 1852 at the Vaudeville [Holff C. 1853: 43]. - Not to be confused with the comic opera 'Les premières armes de Louis XV' [Bernicat F., Carré A. 1888]. - On the same day at Vaudeville also the premiere of 'Alexandre chez Apelles' [Bayard J.-F.-A., Dupin H., 1853]. 
bourgeoisie-and what better avenue than to emulate the floor treatment of bourgeois apartments.

\section{Measuring success}

In the absence of formal media monitoring services and customer surveys, it is difficult to assess the success of Viard's marketing. That at least some of his approaches were highly memorable, and hence successful, has already been mentioned. Significantly, compared to Chromo-Duro-Phane, there is little reference to the marketing of the competitor products, which indicates that their marketing was much more conventional and hence unremarkable. ${ }^{61}$ Yet the rivalry between Viard's Chromo-duro-phane and Raphanel's Siccatif Brillant in the period of about 1850 must have been memorable to some extent, as some authors reference it as a distraction [de Banville T. 1850] or when commenting on other rivalries [Laferté C. 1854].

Some authors commented on the resistance of some people to technological change, bemoaning many changes from the old norm as a social pest ('peste morale'). In a satirical piece pillorying these views, the writer and composer Oscar Comettant [1861: 190] listed Chromo-Duro-Pahne as an important invention and advancement to life style in the same vein as photography ('daguerreotype'), rubber ('caotchouc'), and artificial teeth ('osanores') [same text in Comettant O. 1864: 303].

Another measure of success may be derived from the observation that the brand name had become so well known as a hard wearing, glossy varnish, that writers alluded to it in bon môts as well as in word play-Chromo-duro-phane had become a proprietary eponym. There are several examples of 'chromo-duro-' having become the short hand for 'gloss':

- "La politesse est le chromo-duro-phane de la société française," ${ }^{62}$

- Chromo-duro-fard, ${ }^{63}$

- Chromo-duro-financier, ${ }^{64}$

${ }^{61}$ Rapahnel's 'siccatif Brillant', for example, was heavily advertised in the newspapers. See examples reproduced in Spennemann D.H.R. [2016a].

62 "Politeness is the shining varnish of French society" [Commerson J.L.A. 1851]. Also reported in the variation "La politesse est le chromo-duro-phane de la société canadienne" [Commerson J.L.A. 1854a].

${ }^{63}$ Chromo-duro-makeup [Véron P. 1869: 89].

${ }^{64}$ Self-explanatory; Alhoy M. [1854: 244]. 


\begin{tabular}{|c|c|c|c|c|c|c|c|c|c|c|c|c|c|c|c|}
\hline Year & $\begin{array}{l}\infty \\
\infty \\
\infty\end{array}$ & 움 & $\underset{+}{\stackrel{F}{+}}$ & 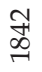 & 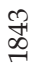 & $\underset{+}{\mathbb{E}}$ & 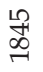 & $\stackrel{0}{\infty}$ & 今+ & 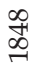 & $\underset{+}{\stackrel{O}{+}}$ & $\begin{array}{l}\stackrel{\infty}{\infty} \\
\stackrel{\infty}{\sim}\end{array}$ & $\underset{\substack{\infty \\
\infty}}{\infty}$ & $\begin{array}{l}\text { Nิ } \\
\infty \\
\infty \\
\sim\end{array}$ & $\underset{\substack{\infty \\
\infty}}{\infty}$ \\
\hline $\begin{array}{l}\text { Address } \\
\text { Books }\end{array}$ & & & & & & $X$ & $x$ & & & & & & & $x$ & $X$ \\
\hline $\begin{array}{l}\text { News- } \\
\text { papers }\end{array}$ & & & & & $X$ & $X$ & $x$ & & & & & & $x$ & & $x$ \\
\hline $\begin{array}{l}\text { Advertis- } \\
\text { ing cards }\end{array}$ & & & & & & & & $X$ & & ? & & & & & \\
\hline $\begin{array}{l}\text { Roaming } \\
\text { Painters }\end{array}$ & & & & & & & & & ? & ? & ? & $x$ & $X$ & $?$ & \\
\hline $\begin{array}{l}\text { Poster } \\
\text { Campaign }\end{array}$ & & & & & & & & & & $X$ & $x$ & & & & \\
\hline $\begin{array}{l}\text { Street } \\
\text { Spectacles }\end{array}$ & & & & & & & & & & & & & $X$ & & \\
\hline
\end{tabular}

Figure 14. Chronology of Viard's marketing of Chromo duro phane 1839-1853

Source: own study.

- Chromo-dur-aux-femmes, ${ }^{65}$

- le chromodurophane de la pensée, ${ }^{66}$

- $\quad$ remplacer le] sauce tomate par chromo-duro-phane ${ }^{67}$

- remplacer le sang du porc par chromo-duro-phane ${ }^{68}$

In 1856 the journalist Jules Viard, who was also the co-editor of Le Figaro, published the small magazine Le Polichinelle à Paris. The magazine Le Tintamarre went to town on critiquing the venture, making a play on the similarity of the surname:

- "Nous confierons le sous-sol de la Comète à M. Viard, le chromodurophane des échos de Paris"69

65 Chromo-dur-among-women Holff C. 1853: 43]. The 'Chromo-dur-aux- femmes' is phonetically very close to chromo-duro-phane.

66 The chromo-duro-phane of thought' as coined by Commerson [1854b: 57f] in is discussion of the French poet, dramatist, novelist, journalist, and critic Théophile Gautier. Commerson also references Viard's competitor Raphanel, by describing Théophile Gautier in the same sentence as the 'Raphanel of current literature.'

67 Sulpice [1874].

${ }^{68} \mathrm{MM}$. les charcutiers ont bien voulu avouer eux-mêmes, qu'ils avaient été réduits à remplacer le sang de porc par du chromo-duro-phane, pour satisfaire leur immense clientèle du réveillon [Maxime 1875].

69 "We will entrust the basement of the Comet [a magazine, ed.] to Mr. Viard, the chromo-duro-phane of the echoes of Paris" Commerson J.L.A. 1857; reprinted 1872]. 
- “La feuille de Jules Viard a été le chromo-duro-phane de la Presse périodique" 70

In 1854, after Viard had gone into liquidation, Alhoy M. [1854: 244] pilloried a fictitious company, the 'Société de crédit chromo-duro-financier,' which was imbued with many negative connotations. ${ }^{71}$

The majority of these allusions and references date to the period from the 1850 s to the 1870 s, suggesting that such cultural references were limited to one generation.

\section{AFTERMATH}

Viard successfully employed the full palette of promotional options available to him. As far as can be ascertained, none of his competitors performed nearly as well in that regard, nor did any other medium-scale entrepreneur at that time.

One then wonders what went wrong. Why did Viard have to declare bankruptcy in 1853 rather than growing to become one of the leading paint manufacturers in France? In the absence of company records, we can only speculate. There may be two explanations. On the one level, Viard's product was highly specialised, a varnish for wooden floors, the annual painting of which, by-and-large would have been limited to the middle- and upper classes of society in Paris and the departmental cities. While the lower middle and working class households may have had wooden floors, the painting of these would not, or only occasionally have been on an annual basis, and, in all probability, would have been carried out by the more labour intensive, but cheaper, traditional oil and wax based methods. Thus, while the market was steady, as it was an annual process, it was no one that offered substantial room for expansion, even if Viard's had only one serious competitor (Raphanel). While the gentrification of Paris was a continual process, it occurred at a steady but slow rate until the Hausmann reorganisation of the late 1850s to 1860s.

The same applied to Viard's 'couleurs hydrofuges,' which were byand-large limited to buildings suffering from damp. This was restricted to

\footnotetext{
70 "The publication of Jules Viard was the chromo-duro-phane of the perodical Press [Martin E. 1857].

${ }^{71}$ For example, the bankers issuing the shares were "Messieurs Vultures and Co" and the Managing entity was "Stubborn and Co.".
} 
older buildings in poorer neighbourhoods, as well as the ground floors of other buildings.

The most significant development in paint systems during the late 1840s and early 1850s was the development of zinc-white (blanc de zinc) which offered an environmentally much safer alternative to the common white lead paint [see discussion in Spennemann D.H.R. 2017b]. While Viard's varnish was limited to the floors, zinc white was applied to all walls, thus requiring a much greater quantity of paint. Moreover, the market for that paint straddled all socio-economic strata of society. While Viard started the production of his own zinc-white (blanc d'Aubervilliers), he was only one of several manufacturers, all bar one [Stanislas Sorel; Spennemann D.H.R. 2020, 2021] who relied on the same zinc oxide supplied by the Société de zinc de la Vieille-Montagne. Moreover, the mixing of zinc oxide-based paints, as developed by Leclaire was a much more simple process than the manufacture of a fast drying varnish. In consequence, a large number of entrepreneurs mixed their paint for immediate application or for on-sale. In that crowded market, Viard never achieved the traction that was needed and his investment failed.

The other cause for his demise may well have been his company structure. The 1840s and 1850s were a period of major transition from individual small-scale artisanal production to either larger factories or to organized co-operating entities. David Landes [1949] characterised the French entrepreneur of the time as a small businessman acting for himself, drawing credit from limited clientele of trusted friends, but being fundamentally conservative and independent. ${ }^{72}$ Louis Viard fits that bill. As far as we can tell, his firm was always a fully privately-owned company without any partners. In this Viard fundamentally differed from other small entrepreneurs of the time, who set up limited partnerships, with themselves as managing director. They used the additional funds to leverage both improved market position, but in particular reputation which allowed them to obtain more powerful financial backers. ${ }^{73}$ At a time when Viard needed connections and financial backing to gain and then maintain a major share of the blanc-de zinc market, it seems he was on his own and his previous independence worked against him.

\footnotetext{
72 While some of Landes' assertions have come under criticism as being too broad and sweeping, the underlying concepts still apply.

${ }^{73}$ For example see Viard's contemporary, Hector Ledru [Spennemann D.H.R. 2017c].
} 
This, however, should not have precluded investors from supporting his venture should he have sought to obtain funds. It is thus likely that other factors also played a role. We can only speculate, but it is quite possible his reputation for loud advertising, which served him so well in the past, as well as his liberal handling of the truth with regards to awards by industry, may have finally caught up with him, making potential investors more cautious than otherwise would have been the case.

\section{CONCLUSIONS}

As noted, the extant literature on French advertising in newspapers and on billboard hoardings focusses on the newspaper publishers, the types of advertisements published, the artistic merit of bill posters or the nature of governmental oversight of the press and bill posting. To date there has only been one paper that examined French advertising from the angle of an entrepreneur trying to promote his wares [Spennemann D.H.R. 2018].

The present paper study demonstrated how during the early to midnineteenth century an essentially media-savvy French entrepreneur could ensure that his products were not only noted by the public, but that his approaches to promoting them also became the talk of the town. In promoting his products, Viard's relied on newspapers only as a means of marketing and promotion during the early days of product introduction. This holds true for Chromo-Duro-Phane (1843-45) as well as his blanc de zinc (1851-53). Once the product had been made known to the educated and newspaper-reading audience of the bourgeoisie, Viard deployed additional methods to both deeper embed the product recognition and broaden his client base. These strategies included billboard advertising that first made people laugh, and then talk about Viard's advertising approaches and thereby reinforce product recognition. By ensuring product placement in Vaudeville shows coupled with the distribution of advertising cards during intermissions, Viard further reinforced brand recognition among the bourgeoisie which, as apartment owners, formed his primary clientele base. While public advertising spectacles added hype, his highly visible itinerant workers ensured commercial success. With their dress, they fulfilled both a brand-reaffirming promotional ploy, but at the same time could also, if desired, provide the required service on the spot, thus converting promotion-derived interest into an immediate sale. Moveable advertising on his wagons allowed him to parade small sections of wooden 
floors through the streets of Paris which had been treated with his product and were for all to see and to touch.

When contrasting Viard's range of promotional activities with those of his contemporary, Stanislas Sorel, differences are stark. Sorel was much more focussed on invention than on commercial success as evidenced by his approach to promoting his portable stove [Spennemann D.H.R. 2017a, 2018], his galvanisation process [Spennemann D.H.R. 2016c] as well as his zinc-based paints [Spennemann D.H.R. 2020, 2021]. While Sorel used experiential marketing for his stoves, all other promotion was purely newspaper based. Other entrepreneurs also heavily relied on newspaper advertisements, ${ }^{74}$ or, depending on the nature of their business, on billboards and hoardings. ${ }^{75}$

While more detailed studies of additional entrepreneurs, in different lines of business, are required to flesh out the history of French advertising from the viewpoint of the manufacturer, it is likely that Louis Viard was in a league of his own. The fact that his bill posters for Chromo-Duro-Phane were remembered by the public thirty years after he ceased his business clearly attests to his acumen and skill.

\section{REFERENCES}

About E. (1855), Voyage à travers l'Exposition des beaux-arts (peinture et sculpture), Hachette, Paris.

Alhoy M. (1854), Mémoires de Bibboquet: Recueillis Par un Bourgeois de Paris, vol. 2, Librairie nouvelle, Paris.

Aminzade R. (1984), Reinterpreting capitalist industrialization: A study of nineteenthcentury France: Proletarianization, small $\square$ scale industry and capitalist industrialization, Social History, 9(3), 329-350.

Anonymous (1843), Chronique, Gazette des Tribunaux, Journal de Jurisprudence et des Débats Judiciares, 18 (5146), , Oct 13, 1265 col. d.

Anonymous (1844a), Chromo-Duro-Phane, Mixtion Anglaise, Kurjer Warsawski, 45, Feb 16, 2 col. b.

Anonymous (1844b), Exposition Publique des Produits de l'industrie Française en 1844. Suite de l'état des récompenses accordées par le jury centrale de l'eposition de 1844 (1), Bulletin de la Société d'Encouragement pour l'Industrie Nationale, 43(483), 365-378.

Anonymous (1844c), Exposition publique des produits de l'industrie française, 1844 (catalogue officiel), Paris: s.n.

${ }^{74}$ E. g. Hector Ledru, Sorel's erstwhile partner in the galvanisation business [Spennemann D.H.R. 2017c] or most book publishers [Feyel G. 2003].

75 Primarily theatre and circus [Feyel G. 2003]. 
Anonymous (1844d), Lettres Parisiennes, Courrier des Alpes. Journal de la Savoy et des États Sardes, 2 (37), Mar 26, 3 col.c.

Anonymous (1845), Feuilleton de la France Théatrale. Les Jésuites et le Portier de M Eugéne Sue, La France Theatrale, 13 (60), Jul 27, 1.

Anonymous (1847), Tribunal de Commerce. Failltes, Gazette des Tribunaux, Journal de Jurisprudence et des Débats Judiciares, 21 (6230), Oct 6, 1229 col. g.

Anonymous (1851a), Le Jeudi de la Mi-Caréme, Le Ménestrel: Journal de musique, 18 (18), Mar 30, 3.

Anonymous (1851b), Paris, Journal des débats politiques et littéraires, Mar 29, 2 col. a-e, http:/ / gallica.bnf.fr/ark:/12148/bpt6k449051b, accessed 1.09.2021.

Anonymous (1852), La découverte du blanc de zinc, La Presse, 16, Nov 29, 2 col. a.

Anonymous (1853a), Barniz para los suelos [Advertisement], La Época, 5 (1384), Sep 14, 4 col. a-b.

Anonymous (1853b), Le blanc de plomb et le blanc de de zinc, La Presse, Apr 5, 2 col. c.

Anonymous (1853c), Le blanc de plomb et le blanc de de zinc, Journal des débats politiques et littéraires, Apr 3, 2 col. b-c.

Anonymous (1854), Paris. Journal de Toulouse, politique et littéraire, 50 (260).

Anonymous (1857), Chromo-Duro-Phane [Advertisement], La Discusion (Madrid), 2 (502), Oct 154, col. c-d.

Ariel (1889), Chronique, La Semaine des familles : revue universelle illustrée, 30 (43), Jan 28, 687-688.

Arnold C.H. (1882), Rauwe en Gekookte Lijnolie. Chromo Duro Phane [Advertisement $\mathrm{n}^{\circ}$ 6149], De Lokomotief. Nieuws-, Handels- en Advertentieblad (Amsterdam), 31 (302), Dec 23, p col. e.

Association for the Exhibition of the Industry of All Nations (1853), Official catalogue of the New York Exhibition of the Industry of All Nations. 1853, G.P. Putnam \& Co, New York.

Barrault-Martin M. (1843), Chromo-Duro-Phane, Journal de Loiret (Orleans), 26 (46), Jun 10, 4 col. e.

Bayard J.-F.-A., Dupin H. (1853), Alexandre chez Apelles, comédie-vaudeville en 1 acte [Paris, Vaudeville, 27 décembre 1852.], Bibliotheque Dramatique, Michel Lévy frères, Paris.

Bernicat F., Carré A. (1888), Les premières armes de Louis XV: opéra-comique en 3 actes d'après la comédie de Benjamin Antier, Enoch frères \& Costallat, Paris.

Bertall (1852), Couleur de Salon de 1852, ou le salon dépeint et dessine. Journal de Rire, 37, Jun $12,1-2$.

Bibliotheque national de France (2015), Gallica, Bibliotheque national de France, Paris, http:/ / gallica.bnf.fr/, accessed 30.11.2015.

Boucher H. (1908), Souvenirs d'un Parisien Pendant la Séconde République (1830-1852), Librairie Académique Perrin et Cie, Paris.

Bouchut E. (1852), Mémoire sur l'hygiène et l'industrie de la peinture au blanc de zinc, J.B Bailliere, Paris.

Bouillet M.-N. (1861), Dictionnaire universel des sciences, des lettres et des arts. (5 ed.), Hachette, Paris.

Bowning E.A. (1852a), Exhibition of the works of industry of all nations, 1851. Reports by the Juries of the Subjects in the Thirty Classes into which the Exhibition was Divided (Corrected Edition), W Clowes \& Sons, London.

Bowning E.A. (1852b), Exhibition of the works of industry of all nations, 1851. Reports by the Juries of the Subjects in the Thirty Classes into which the Exhibition was Divided. (1 Introductory. Awards. Reports, classes I to IV ed.), W Clowes \& Sons, London. 
Bowning E.A. (1852c), Exhibition of the works of industry of all nations, 1851. Reports by the Juries of the Subjects in the Thirty Classes into which the Exhibition was Divided. (Corrected Edition), W Clowes \& Sons, London.

Bowning E.A. (1852d), Exhibition of the works of industry of all nations, 1851. Reports by the Juries of the Subjects in the Thirty Classes into which the Exhibition was Divided. (Corrected Edition), W Clowes \& Sons, London.

Buffet L. (1850a), Rapport de Jury Central sur les produits de l'agriculture et de l'industrie exposés en 1849, vol. I, Imprimerie Nationale, Paris.

Buffet L. (1850b), Rapport de Jury Central sur les produits de l'agriculture et de l'industrie exposés en 1849, vol. II, Imprimerie Nationale, Paris.

Buffet L. (1850c), Rapport de Jury Central sur les produits de l'agriculture et de l'industrie exposés en 1849, vol. III, Imprimerie Nationale, Paris.

Busoni P. (1851), Courrier de Paris, L'Illustration, Journal Universel, 17 (426), Apr 26, 258259.

Caron F. (1995), Histoire économique de la France, XIXe-XXe siècles, (2 ed.), Armand Colin, Paris.

Chevallier A. (1874), Dictionnalre des substances alimentaires des falsifications qu'on leur fait subir moyen de les reconnaitre, de Roretm Paris.

Chokron S., Kazandjian S., De Agostini M. (2009), Effects of Reading Direction on Visuospatial Organization: A Critical Review [in:] Gari A., Mylonas K. (eds.), Quod erat demonstrandum: from Herodotus' ethnographic journeys to cross-cultural research, Pedio Books Publishing, Athens, 107-114.

Claude A., Labourieu T. (1883), Mémoires de M. Claude, chef de la police de sûreté sous le second Empire, vol. 10, J. Rouff, Paris.

Comettant O. (1861), La Peste de 1624 et la Peste de 1861, Musée littéraire: choix de littérature contemporaine française et étrangère, 29, 189-191.

Comettant O. (1864), En Vacances, Achille Fuare, Paris.

Commerson J.L.A. (1851), Pensées d'un emballeur, Le Tintamarre: critique de la réclame, satire des puffiste, 9, Jul 22, 1 col. b-c.

Commerson J.L.A. (1854a), Pensées d'un emballeur [in:] Chevalier H. E., Cherrier G.-H. (eds.), La Ruche Litteraire et Politique, Vol. 3, Senécal et Daniel, Montreal, 89-90.

Commerson J.L.A. (1854b), Théophile Gautier [in:] Citbouillard J. (ed.), Les Binettes Contemporaines Gustave Harvard, Paris, 49-64.

Commerson J.L.A. (1857), La Cométe, Le Tintamarre: critique de la réclame, satire des puffiste, 16, Apr 5, 4 col. b-c.

Commerson J.L.A. (1872), La Cométe, Le Tintamarre: critique de la réclame, satire des puffiste, 16, Jan 14 , 4 col. b-c.

Commission Impériale (1855), Exposition des produits de l'industrie de toutes les nations 1855. Catalogue officiel publié par ordre de la Commission Impériale. E Panis. Paris.

Cook J. (1999), Mass marketing and cultural history: the case of PT Barnum, American Quarterly, 51(1), 175-186.

Coulier P.-J. (1852), Question de la céruse et du blanc de zinc envisagée sous les rapports du commerce, des arts et de l'hygiène, J B Bailliere., Paris.

Cox D., Nye J.V. (1989), Male-female wage discrimination in nineteenth-century France, The Journal of Economic History, 49(4), 903-920.

Crawford R., Brennan L., Khamis S. (2020), Decoding Coca-Cola: A Biography of a Global Brand, Routledge, Abingdon.

Darmesteter A. (1877), De la création actuelle de mots nouveaux dans la langue française et des Lois 1qui la regissent, F. Vieweg, Paris. 
Darthenay (1851), La Fête de l'Agriculture. Le Nouvelliste : quotidien politique, littéraire, industriel et commercial, Mar 4, 2 col. b-c.

Datz P. (1894), Histoire de la publicité depuis les temps les plus reculés jusqu'à nos jours, J. Rothschild, Paris.

de Banville T. (1850), Montansier: Embrassons-nous, Folleville, comédie de MM. Lefranc et Labiche. Le Dix décembre: journal de l'ordre, Mar 11.

de Genouillac, H.G. (1882), Paris à travers les siècles - Histoire nationale de Paris et des Parisiens depuis la fondation de Lutèce jusqu'à nos jours - Costumes de Paris à travers les siècles, F. Roy, Paris.

de Morveau G. (1783), Recherches pour perfectionner la préparation des couleurs employées, Nouveaux mémoires de l'académie de Dijon pour la partie des sciences et des arts, premier semestre, 1782, 1-24.

de Rattier P.E. (1857), Paris n'existe pas, s.l, Paris.

de Saint Aure J. (1844), Exposition nationale de 1844 (deuxiéme article), Gazette des Tribunaux, Journal de Jurisprudence et des Débats Judiciares, 19 (5375), 908.

Department de l'Oise (2015, 13.09.1814), Naissances, mariages, décés avec tables alphabétiques 1810-1816. État civil numérisé de Lachapelle-aux-Pots, 1MI/ECA333R3, 1 E 7, Acte de naissance $n^{\circ} 21$ de l'année 1814, Archives départementales de l'Oise, Beauvais.

Dollingen (1844), Exposition des Produits de l'Industrie Nationale, Troisieme Article, La Sylphide (Revie Parisienne), 10, 41-44.

Dominguez R.J. (1845), Diccionario Universal Francés-Español por una Sociedad de Professores de Ambas Lenguas, vol. 1, Jordan e Hijos, Madrid.

Doraszelski U. (2004), Measuring returns to scale in nineteenth-century French industry, Explorations in Economic History, 41(3), 256-281.

Duckett W. (1867), Dictionnaire de la conversation et de la lecture : inventaire raisonné des notions générales les plus indispensables à tous, par une société de savants et de gens de lettres, 2 ed., Firmin Didot, Paris, frères.

Dupin C. (1836a), Rapport du jury central sur les produits de l'industrie française exposés en 1834, vol. 1, Imprimerie Royale, Paris.

Dupin C. (1836b), Rapport du jury central sur les produits de l'industrie française exposés en 1834, vol. 2, Imprimerie Royale, Paris.

Dupin C. (1836c), Rapport du jury central sur les produits de l'industrie française exposés en 1834, vol. 3, Imprimerie Royale, Paris.

Duverger P. (1864), Causerie, L'Europe Artiste, 12 (25), Jun 19, 1.

Edmonson J.M. (1981), From Mecanicien to Ingenieur: Technical Education and the Machine Building Industry in Nineteenth-Century France, University of Delaware, thesis.

Eldesouky D.F.B. (2013), Visual Hierarchy and Mind Motion in Advertising Design, Journal of Arts and Humanities, 2(2), 148-162.

Elting J.R. (1993), Napoleonic Uniforms, Macmillan Publishing Company, London.

Fauvel M. (1851a), Chromo-Duro-Phane, Journal d'Argentan, 37 (49), Jun 194, col. d.

Fauvel M. (1851b), Fauvel, Epicier a Argentan, Journal d'Argentan, 37 (82), Oct 13, 4 col. d.

Feyel G. (2003), Presse et publicité en France (XVIIIe et XIXe siècles), Revue historique, $4(628), 837-868$.

Firmin-Didot A., Firmin-Didot H. (1857), Annuaire Gènéral du Commerce et de l'Industrie ou Almanach des 500,000 Adresses, Didot, Paris.

Firmin-Didot A., Firmin-Didot H. (1862), Annuaire Gènéral du Commerce, de l'Industrie, de la Magistrature et de l'administration ou Almanach des 500,000 Adresses. (22 ed.), Didot, Paris. 
Firmin-Didot A., Firmin-Didot H. (1864), Annuaire Gènéral du Commerce, de l'Industrie, de la Magistrature et de l'administration ou Almanach des 500,000 Adresses. (24 ed.), Didot, Paris.

Flamant P. (1850), Petits Industries, L'Illustration. Journal universel, 398, Oct 4, 236.

Flammèche N. (1873), Les Marrons de Feur, Le Grelot: journal illustré, politique et satirique, 3 (103), Mar 30.

Frey J. (1844), Feuilleton du Mercure des Théatres. Courier de Paris. Beaux Arts-ModesIndustrie, Mercure des Théatres. Beaux Arts-Modes-Industrie, 2, Sep 1, 1-2.

Gale (2015), The Times Digital Archive 1785-2011 [data base], Gale Cengage Learning, London, http:// www.nla.gov.au/app/eresources/item/1088, accessed 1.09.2021.

Gale, British Library (2015), British Newspapers 1600-1950 [data base], Gale Cengage Learning, London, http:/ / www.nla.gov.au/app/eresources/item/4314, accessed 1.09.2021.

Gervais T. (2005), Imaging the world. L'Illustration: the birth of the French illustrated press and the introduction of photojournalism in the mid-19th century, Medicographia, 27(1), 97-106.

Girardin J.P.L. (1861), Leçons de chimie élémentaire appliquée aux arts industriels. Chimie organique, vol. 3, G. Masson, Paris.

Göbel S.M. (2015), Up or down? Reading direction influences vertical counting direction in the horizontal plane - a cross-cultural comparison, Frontiers in Psychology, 6(228), 1-5.

Goodison N. (1968), English Barometers, 1680-1860; a history of domestic barometers and their makers, C. N. Potter, New York.

Graham T. (1852), Class II. Report on Chemical and Pharmaceutical Processes and Products Generally [in:] Bowning E. A. (ed.), Exhibition of the works of industry of all nations, 1851. Reports by the Juries of the Subjects in the Thirty Classes into which the Exhibition was Divided, Corrected Edition ed., W Clowes \& Sons, London, 37-50.

Guenée A. (1843 [1844]), Des Nom en Entomologie. Recueil des Travaux de La Societe Libre D'agriculture, sciences, arts et belles-lettres de l'Eure, 4, 358-372.

Hahn H.H. (2010), Scenes of Parisian Modernity: Culture and Consumption in the Nineteenth Century, Palgrave Macmillan, Basingstoke.

Han S., Northoff G. (2008), Reading direction and culture, Nature Reviews Neuroscience, 9(965), 646-654.

Hardach G.H. (1969), Der soziale Status des Arbeiters in der Frühindustrialisierung; eine Untersuchung über die Arbeitnehmer in der französischen eisenschaffenden Industrie zwischen 1800 und 1870, Duncker \& Humblot, Berlin.

Hendon D.W., Muhs W.F. (1985), Origin and Early Development of Outdoor Advertising in the United States [in:] Sheth J.N., Tan C.T. (eds.), Historical Perspective in Consumer Research: National and International Perspectives, Association for Consumer Research, Singapore, 309-313.

Henrichs P. (1853), Annuaire Gènéral du Commerce et de l'Industrie ou Almanach des 500,000 Adresses, 16 ed., Didot, Paris.

Héricart-Ferrand de Thury L.-É.-F. (1824), Rapport sur les produits de l'industrie Française présenté au nom de jury central, vol. 1, Imprimerie Royale, Paris.

Héricart-Ferrand de Thury L.-É.-F., Migneron M. (1828), Rapport sur les produits de l'industrie Française présenté au nom de jury central, vol. 1, Imprimerie Royale, Paris.

herve168 (2016), Ancienne Etiquette “Chromo Duro Phane" Viard-Paris [on-line auction], eBay. http://www.ebay.com/itm/111639729416, accessed 12.04.2016.

Heywood C. (1995), The Development of the French Economy 1750-1914, Cambridge University Press, Cambridge. 
Hiatt C. (1896), Picture Posters: A short history of the illustrated placard, with many reproductions of the most artistic examples in all countries, 2 ed., George Bell \& Sons, London.

Holff C. (1853), Vaudeville [in:] de Goncourt E., de Goncourt J., Holff C. (eds.), Mystéres de Theatres 1852, Libraire Nouvelle, Paris, 39-43.

Hultquist C.E. (1996), The Price of Dreams: A History of Advertising in France, 1927-1968, Ohio State University, thesis.

Institut de France (1878), Dictionnaire de l'Académie Française, (7 ed.), vol. 2 I-Z, Firmin-Didot, Paris.

Irwin D.A. (1993), Free trade and protection in nineteenth-century Britain and France revisited: a comment on Nye, The Journal of Economic History, 50(1), 146-152.

Jean de Paris (1876), Physionomie des Elections, Le Figaro, 28 (52), Feb 21, 1-2.

Jean de Paris (1892), Nouvelles Diverses, Le Figaro, 38 (34), Feb 34, col. e-f.

Labourieu T. (1853), Voyage a travers de l'industrie. Le Tintamarre: critique de la réclame, satire des puffiste, 11, Aug 7, 6-7.

Laferté C. (1854), Le Temple-Neuf et les docks-de-la-toilette, Le Journal pour rire: journal d'images, journal comique, critique, satirique, lithographique, 135, Apr 29, 4-5.

Lalire C. (1851), Correspondance. Mi-Caréme, L'Artiste: revue hebdomadaire du Nord de la France.

Landes D.S. (1949), French Entrepreneurship and Industrial Growth in the Nineteenth Century. The Journal of Economic History, 9, 45-61.

Larousse P. (1869), Grand dictionnaire universel du XIXe siècle: français, historique, géographique, mythologique, bibliographique, vol. 4 Chemin-Contray, Administration du grand Dictionnaire universel, Paris.

Le cadastre de Paris par îlot, dit atlas Vasserot (1810-1836), plan 7eme arrondissement, 25eme quartier Sainte-Avoye, Archives numérisées de Paris, Archives de Paris, îlot n¹5, $\mathrm{F} / 31 / 86 / 30$.

Lefebvre T. (2003), Tramways et réclame pharmaceutique [Question XLII, Transports en commun et publicité pharmaceutique], Revue d'Histoire de la Pharmacie, 91(340), 690.

Lemercier C. (2009), Looking for "Industrial Confraternity" Small-Scale Industries and Institutions in Nineteenth-Century Paris, Enterprise \& Society, 10(2), 304-334.

Levy-Leboyer M., Bourguignon F. (1990), The French economy in the nineteenth century: an essay in econometric analysis, Cambridge University Press, Cambridge:

Lloyd A.J. (2007), Advertising. British Library Newspapers, Gale, Detroit, https:/ / www.gale. com/intl/essays/amy-j-lloyd-advertising, accessed 1.09.2021.

Louis Philippe (1844), No 11, 236 - Ordonnance du Roi portant proclamation des brevets d'invention deliverés pendent le quatrtème trimestre de 1843. Bulletin des Lois du Royaume de France, 28(1088), 299-349.

Machlup F., Penrose E. (1950), The Patent Controversy in the Nineteenth Century, The Journal of Economic History, 10(1), 1-29.

Magnac T., Postel-Vinay G. (1997), Wage Competition between Agriculture and Industry in Mid-Nineteenth Century France, Explorations in Economic History, 34(1), 1-26.

Maindron E. (1896), Les Affiches illustrées, 1886-1895, G. Boudet \& Ch. Tallandier, Paris.

Martin E. (1851), Causeries, Le Tintamarre: critique de la réclame, satire des puffiste, 9, Mar 30, 2 col.b- c.

Martin E. (1857), Biggarures, Le Tintamarre: critique de la réclame, satire des puffiste, 16 (392), May 3, 4 col. c-5 col.a.

Martin M. (1992), Trois siècles de publicité en France, Éditions Odile Jacob, Paris.

Martin M. (1994), L'affiche de publicité à Paris et en France à la fin du XIXe siècle [in:] La terre et la cité, mélanges offerts à Philippe Vigier, Créaphis, Paris, 373-387. 
Martin M. (2004), De l'affiche à l'affichage (1860-1980). Sur une spécificité de la publicité française, Le Temps des médias, 2, 59-74.

Maxime (1875), La fin de la fin, Le Tintamarre: critique de la réclame, satire des puffiste, 34, Jan 33, col. c-4 col. a.

Mercier L.-S. (1782), Tableau de Paris. Nouvelle Edition ed., 2, Amsterdam.

Mermet E. (1878), La Publicité en France, guide pratique. Annuaire pour 1878, précédé de notices historiques sur les différents modes de publicité en usage en France et d'un traité juridique sur l'enseigne, l'affiche, l'annonce et le colportage, mis au courant de la législation et de la jurisprudence jusqu'au 1er mai 1878, impr. de A. Chaix, Paris.

Mermet E. (1879), La Publicité en France. Histoire et Jurisprudence, impr. de A. Chaix, Paris.

Migne J.-P. (1857), Troisième et dernière Encyclopédie théologique, vol. 28, J P Migne, Paris.

Millea A. (2016), Monsieur Wilson, ex-Professor of Chemistry of the University of Oxford, Personal Communication by Assistant Keeper of the University Archives, Oxford. Spennemann D.H.R., 3.05.2016.

Ministère de l'agriculture et du commerce (1849), Exposition nationale des produits de l'agriculture et de l'industrie en 1849. Distribution des récompenses par le président de la République, Typographie Panckouke, Paris.

Monmory (1845), Siccatif Luisant, La Presse, 10 (3494), Nov 23, 4 col. f.

Monmory, Raphanel (1842), Siccatif Brilliant. Exposition 1842, La Presse, Nov 13, 4 col. c-d.

Monmory, Raphanel (1843), Siccatif Brilliant. Exposition 1842 [Advertisement no 4618], La Presse, 11 (3799), Apr 6, 4 col. e-f.

Monmory, Raphanel (1849), Composition.... Journal de chimie médicale, de pharmacie, et de toxicologie, 579-580.

Moser P. (2003), How do patent laws influence innovation? Evidence from nineteenth-century world fairs, Mass National Bureau of Economic Research, Cambridge.

Musée d'Orsay (2006), Alexandre Joseph Oliva. Rembrandt, vers 1853, Oeuvren7054, http:/ / www.musee-orsay.fr/fr/collections/catalogue-des-oeuvres/notice.html?nnumid= 7054, accessed 20. 04. 2016.

Napoléon P. (1856), Exposition Universelle de 1855. Raports de Jury Mixte International, vol. 1, Imprimerie Impériale, Paris.

National Library of Australia (2016), Trove, National Library of Australia, Canberra, http:/ / trove.nla.gov.au, accessed 3.05.2016.

Newell J., Salmon C.T., Chang S. (2006), The hidden history of product placement. Journal of Broadcasting \& Electronic Media, 50(4), 575-594.

Nye J.V. (1991), The Myth of Free-Trade Britain and Fortress France: Tariffs and Trade in the Nineteenth Century, The Journal of Economic History, 51, 23-46.

Pape W. (1914), Handwörterbuch der griechischen Sprache, (3 ed.), vol. 2, Friedrich Vieweg \& Sohn. Braunschweig.

Pendergrast M. (2000), For God, Country and Coca-Cola. The Unauthorized History of the Great American Soft Drink and the Company That Makes It, Orion Business Books, London.

Préfecture de police (1850), Affiche, Jan 10, Avis. Fabrique de Vernis. 25 Fi. Collection des affiches de Commodo et Incommodo. Enquête de la Préfecture de police. Implantation à Aubervilliers, 25 Fi 714 Archives municipales de Saint-Denis.

Presbrey F. (1929), The history and development of advertising, Doran \& Company, Doubleday.

Ratcliffe B.M. (1994), Manufacturing in the metropolis: the dynamism and dynamics of Parisian industry at the mid-nineteenth century, The Journal of Economic History, 23(2), 263-266. 
Republique Francaise (1852), No 6,131 Décrets du President de la Republique. Bulletin des Lois de la Republique, 8(223), 749-750.

Richard J. (1869), Gazette Electorale, Le Figaro, 16 (131), May 12, 2 col. b-c.

Sachs K., Villatte C. (1869), Enzyklopadisches Worterbuch der franzosischen und deutschen Sprache: mit Angabe der Aussprache nach dem phonetischen System der Methode ToussaintLangenscheidt, vol. 1, Französisch-deutsches Wörterbuch, G. Langenscheidt, BerlinSchöneberg.

Sampson H. (1874), A history of advertising from the earliest times, Chatto and Windus, Edinbugh and London.

Sarcey F. (1882), Le mot et la chose, Paul Ollendorff, Paris.

Ségoïllot H. (1870), Lettres sur l'Espagne, A. Lacroix, Paris, Verboeckhoven et Cie.

Segrave K. (2004), Product placement in Hollywood films. A history, McFarland, Jefferson, NC.

Sicsic P. (1991), Labor markets and establishment size in nineteenth century France, Department of Economics, Harvard University, Cambridge, MA thesis.

Sicsic P. (1992), City-farm wage gaps in late nineteenth-century France, The Journal of Economic History, 52(3), 675-695.

Silliman B., Johnson B.P., Webber S. (1853), Association for the Exhibition of the Industry of All Nations. Official awards of Juries, W. C. Bryant \& \& Co., New York.

Smith M.S. (2006), The Emergence of Modern Business Enterprise in France, 1800-1930, Harvard University Press, Cambridge.

Sorré (1852), La vérité sur le blanc de zinc, De Léclére, Paris.

Soudée, R. (1852), Question de la céruse et du blanc de zinc envisagée sous les rapports du commerce, des arts et de l'hygiène, Beaule et Cie, Paris.

Spennemann D.H.R. (2016a), Advertisements for Chromo-Duro-Phane varnish in nineteenth century French newspapers. A visual data set, Institute for Land, Water and Society, Charles Sturt University, Albury, technical report, doi:10.13140/RG.2.2.23988.17288.

Spennemann D.H.R. (2016b), The Biographical Background of the paint manufacturer Louis Jean Baptiste Servais Viard (1816-1868), Institute for Land, Water and Society, Charles Sturt University, Albury, technical report, doi: 10.13140/RG.2.2.10566.40004.

Spennemann D.H.R. (2016c), The Société pour la Galvanisation du Fer as reflected in contemporary advertisements, Institute for Land, Water and Society, Charles Sturt University, Albury, technical report, doi:10.13140/RG.2.2.17277.28642.

Spennemann D.H.R. (2017a), Advertisements for Stanislas Sorel's portable stove 'Le Cordon Bleu' (1833-1849). A visual data set, Institute for Land, Water and Society Report, 101, Institute for Land, Water and Society, Charles Sturt University, Albury.

Spennemann D.H.R. (2017b), Blanc de Zinc: advertisements for zinc oxide-based paints in midnineteenth century French newspapers, Institute for Land, Water and Society, Charles Sturt University, Albury NSW, technical report, doi:10.13140/RG.2.2.23201.74089.

Spennemann D.H.R. (2017c), Bourgeois Aspirations: A biographical sketch of Hector Ledru, manufacturer and inventor (1798-1876). Zeitschrift für Unternehmensgeschichte, 62(2), 257-297.

Spennemann D.H.R. (2017d), Inventing, Innovating and Investing: Biographical notes on the French inventor of galvanised iron, Stanislas Tranquille Modeste Sorel (1798-1876). Institute for Land, Water and Society Report, 106, Institute for Land, Water and Society, Charles Sturt University, Albury.

Spennemann D.H.R. (2018), Marketing and Promoting a revolutionary cooking appliance in the 1840s. Stanislas Sorel's 'portable stove 'Le Cordon Bleu' (1834-1849), Journal of Historical Research in Marketing, 10(1), 37-59. doi:10.1108/JHRM-06-2016-0015. 
Spennemann D.H.R. (2020), Stanislas Sorel's zinc-based paints, Transactions of the Institute of Metal Finishing, 98(1), 8-13.

Spennemann D.H.R. (2021), Stanislas Sorel and the Origins of Cold Galvanizing, Transactions of the Institute of Metal Finishing, 99(144), doi:10.1080/09538259.2021.1895484.

Sulpice (1874), Dépéches Télégraphiques du Tintamarre, Le Tintamarre: critique de la réclame, satire des puffiste, 9, Nov 22, 5 col. a.

Tanquerel des Planches L.J.C.M. (1839), Traité des maladies de plomb ou saturnines, vol. 2, Ferra, Paris.

Temple P. (2008), Survey of London, vol. 47, Northern Clerkenwell and Pentonville, London County Council, London.

Texier E.A. (1852), Tableau de Paris, vol. 1, Paulin et Le Chevalier, Paris.

Texier E.A. (1854), Le Petits Paris. Paris-Gagne-Petit, Le Petits Paris vol. 8, Ch. de Lahure, Paris.

Texier E.A. (1867a), Kleine Industriezweige [in:] Paris: ein Spiegelbild seiner Geschichte, seines Geistes und Lebens in Schilderungen von den bedeutendsten Schriftsteller Frankreichs, Vol. 1, R Lesser, Berlin, 55-67.

Texier E.A. (1867b), Petits Industries [in:] Paris Guide. Par le principaux ecrivains et artistes de la France, Vol. 2, Libraraire Internationale, Paris, 963-972.

Thénard B. (1839), Exposition de produits de l'industrie Française en 1839. Rapport de Jury Central, vol. 1, L Bouchard-Huzard, Paris.

Thénard B. (1844a), Rapport de Jury Central. Exposition de produits de l'industrie Française en 1844, vol. 1, de Fain et Cinot, Paris.

Thénard B. (1844b), Rapport de jury central. Exposition de produits de l'industrie Française en 1844, vol. 2, de Fain et Cinot, Paris.

Thénard B. (1845), Extrait du Rapport du Jury Central. Arts Chimiques. Revue scientifique et industrielle, 6 (23), 313-335.

Tripier-Deveaux A.M. (1845), Traité théorique et pratique sur l'Art de faire les Vernis: Suivi de deux, Libraire Scientifique Industrielle, Paris.

Usine Hydraulique à d'Aubervilliers (1853a), Blanc d'Aubervilliers. La Presse, 17, Jul 12, 4 col. 1-e.

Usine Hydraulique à d'Aubervilliers (1853b), Blanc d'Aubervilliers. L'Illustration, Journal Universel, 21 (538), Jun 18, Supplement 4-5.

Usine Hydraulique à d'Aubervilliers (1853c), Blanc d'Aubervilliers. Journal des débats politiques et littéraires, Jul 20, 4 col. 1-e.

Usine Hydraulique à d'Aubervilliers (1853d), Blanc d'Aubervilliers. La Presse, 17, Jul 7, 4 col. $1-\mathrm{e}$.

Verneuil F. (1838), La 4me page des journaux, histoire impartiale de l'annonce et de la reclame depuis leur naissance jusqu'a ce jour, P. Martignon, Paris.

Véron P. (1869), Fantaisies Parisennes. I. La Voiture à Guignol, Almanach comique, pittoresque, drolatique, critique et charivarique, 28, 88-105.

Viard et Charmy (1860), Siccatif sans Frottage, La Presse, 25, Feb 15, 4 col. e-f.

Viard L. (1843a), Chromo-Duro-Phane, La Presse, May 19, 4 col. a-b.

Viard L. (1843b), Chromo-Duro-Phane [advertisement n ${ }^{\circ}$ 1050], La Presse, Aug 14, 4 col. $\mathrm{a}-\mathrm{b}$.

Viard L. (1843c), Chromo-Duro-Phane [advertisement $n^{\circ} 1761$ ], Journal des débats politiques et littéraires, Apr 9, 4 col. e-f.

Viard L. (1844a), Chromo-duro-Phane, Mercure des Théatres. Beaux Arts-Modes-Industrie, 2, Sep 29, 4 col. d. 
Viard L. (1844b), Chromo-Duro-Phane [advertisement n ${ }^{\circ}$ 3591], Journal des débats politiques et littéraires, Jul 1, 4 col. c-d.

Viard L. (1844c), Couleurs Hydrofuges, Gazette des Tribunaux, Journal de Jurisprudence et des Débats Judiciares, 19 (5355), Jun 19, 804.

Viard L. (1845a), Chromo-Duro-Phane Le Charivari, 14 (205), Jul 24, 4 col. a-b.

Viard L. (1845b), Chromo-Duro-Phane Le Charivari 14 (236), Aug 24, 4 col. d-e.

Viard L. (1845c), Chromo-Duro-Phane Le Charivari 14 (229), Aug 17, 4 col. a-b.

Viard L. (1845d), Chromo-Duro-Phane Le Charivari 14 (222), Aug 10, 4 col. d-e.

Viard L. (1845e), Chromo-Duro-Phane Le Charivari 14 (215), Aug 3, 4 col. a-b.

Viard L. (1845f), Chromo-Duro-Phane Le Charivari 14 (244), Aug 31, 4 col. a-b.

Viard L. (1851a), Blanc de Zinc, Broyé a Huile, La Presse, Jun 13, 4 col. a-b.

Viard L. (1851b, Jul 25), Peinture au blanc de zinc. [Maison du Chromo-Duro-Phane], Journal des débats politiques et littéraires, 4 col. a-b.

Williams R.J.P., Chapman A., Rowlinson J.S. (2008), Chemistry at Oxford: A History from 1600 to 2005, Royal Society of Chemistry, London.

Wilson G. (1699), A compleat course of chymistry: Containing near Three Hundred Operations; Several of which Havenot been Publish'd before; Also The Structure of several Furnaces with near Three Hundred Characters, which are dispers'd in Chymical Authors; And such Instruments and Vessels as are necessary in a Compleat Elaboratory, 5 ed., Kettilby, London.

Wilson G. (1709), A complete course of chymistry: Containing not only the best chymical medicines, but also great variety of useful observations. To which are added, the author's experiments upon metals, by way of appendix, 3 ed., John Bayley, London.

Wilson G. (1736), A complete course of chymistry: Containing not only the best chymical medicines, but also great variety of useful observations. The fifth edition, carefully corrected, very much enlarged, and illustrated with copper plates. To which are added, the author's experiments upon metals, by way of appendix, 5 ed., J. Osborn, London.

Wren D.A. (2001), Henri Fayol as strategist: A nineteenth century corporate turnaround, Management Decision, 39(5/6), 475-487.

Yapp G.W., Ellis R. (1851), Official catalogue of the Great exhibition of the works of industry of all nations, 1851, (Corrected Edition ed.), Spicer Brothers and W Clowes \& Sons, London.

\section{ACKNOWLEDGEMENTS}

I am indebted to Alice Millea (Assistant Keeper of the University Archives, University of Oxford) for checking on "Professor Wilson's" existence in Oxford.

Dirk H.R. Spennemann researches and teaches Cultural Heritage Management and Environmental History. His current research foci are heritage theory and the history and heritage of Punjabi immigrants during the nineteenth and early twentieth centuries. He just completed a mjor project on the history and heritage of galvanised iron and associated paint treatments during the nineteenth century. 